\title{
The Effects of Missouri River Mainstem Reservoir System Operations on 2011 Flooding Using a Precipitation-Runoff Modeling System Model
}

Chapter K of

2011 Floods of the Central United States

Professional Paper 1798-K 
Front cover. Overflow at Craig, Missouri, with Interstate 29 in the foreground, July 8, 2011. Photograph by Jeff Herzer (jeffherzer.com) and Missouri State Highway Patrol. Pilot: Sgt. Kevin G. Haywood.

Back cover. Overflow at Corning, Missouri, with Interstate 29 in the foreground, July 8, 2011. Photograph by Jeff Herzer (jeffherzer.com) and Missouri State Highway Patrol. Pilot: Sgt. Kevin G. Haywood. 


\title{
The Effects of Missouri River Mainstem Reservoir System Operations on 2011 Flooding Using a Precipitation-Runoff Modeling System Model
}

\author{
By Adel E. Haj, Daniel E. Christiansen, and Roland J. Viger
}

Chapter K of

2011 Floods of the Central United States

Professional Paper 1798-K 


\title{
U.S. Department of the Interior SALLY JEWELL, Secretary
}

\section{U.S. Geological Survey Suzette M. Kimball, Acting Director}

\author{
U.S. Geological Survey, Reston, Virginia: 2014
}

For more information on the USGS - the Federal source for science about the Earth, its natural and living resources, natural hazards, and the environment, visit http://www.usgs.gov or call 1-888-ASK-USGS.

For an overview of USGS information products, including maps, imagery, and publications, visit http://www.usgs.gov/pubprod

To order this and other USGS information products, visit http://store.usgs.gov

Any use of trade, firm, or product names is for descriptive purposes only and does not imply endorsement by the U.S. Government.

Although this information product, for the most part, is in the public domain, it also may contain copyrighted materials as noted in the text. Permission to reproduce copyrighted items must be secured from the copyright owner.

Suggested citation:

Haj, A.E., Christiansen, D.E., and Viger, R.J., 2014, The effects of Missouri River mainstem reservoir system operations on 2011 flooding using a Precipitation-Runoff Modeling System model: U.S. Geological Survey Professional Paper 1798-K, 33 p., http://dx.doi.org/10.3133/pp1798K.

ISSN 2330-7102 (online) 


\section{Contents}

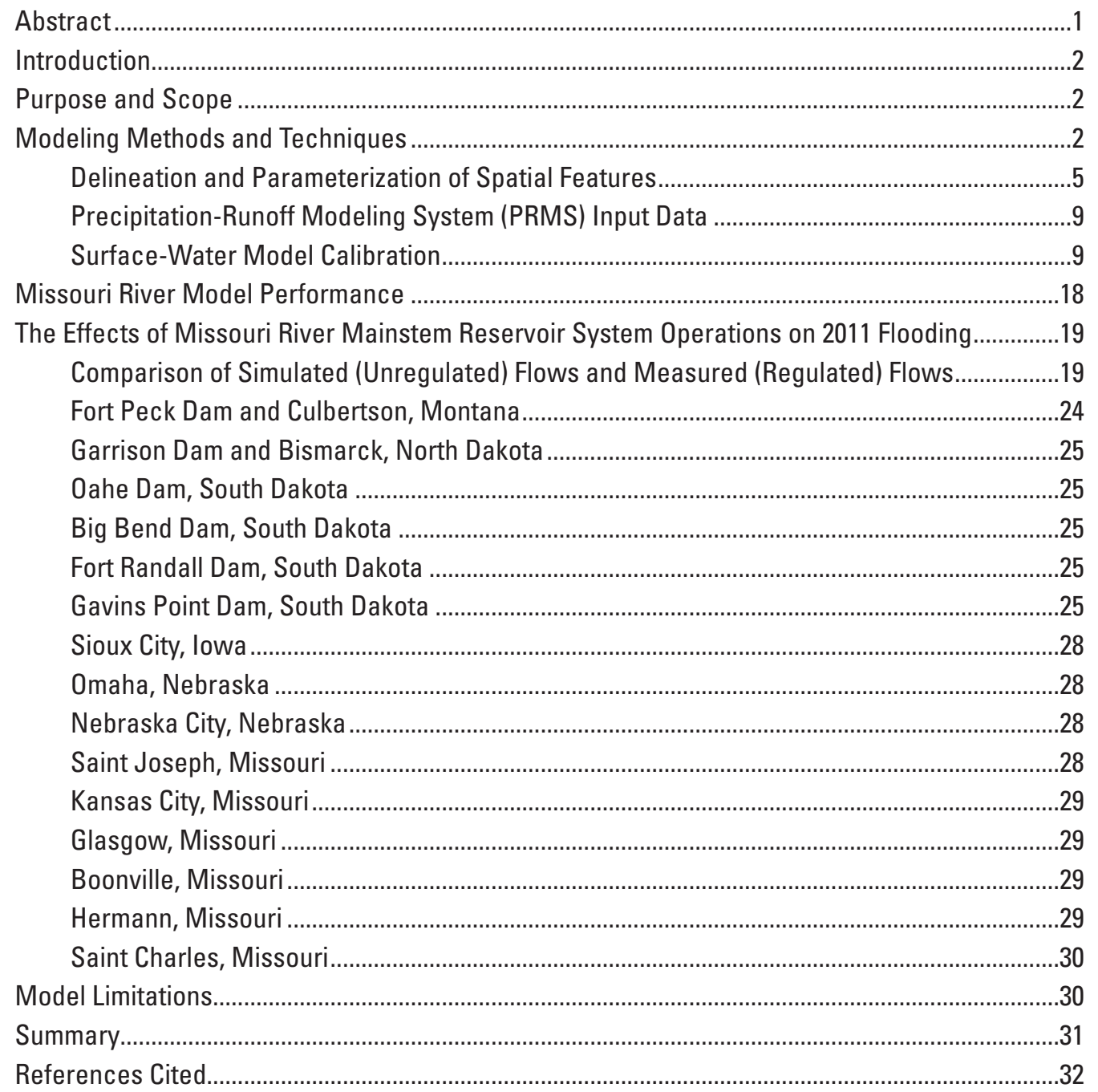




\section{Figures}

1. Map showing location of Missouri River Basin.

2. Map showing location of U.S. Army Corps of Engineers major dams along the Missouri River .

3. Schematic diagram of a watershed and its meteorological inputs (precipitation, air temperature, and solar radiation) simulated by the Precipitation-Runoff Modeling System

4. Map showing subbasins and Hydrologic response units in the Missouri River Precipitation-Runoff Modeling System model

5. Map showing stream segments for the Precipitation-Runoff Modeling System representation of the hydrologic system.

6. Map showing location of U.S. Geological Survey streamgages used in the Missouri River Precipitation-Runoff Modeling System model

7. Graphs showing daily mean streamflow simulated using the Missouri River Precipitation-Runoff Modeling System model as compared to calibration streamflow data sets (simulated unregulated streamflow and naturalized unregulated streamflow, and simulated regulated streamflow and measured regulated streamflow) for selected locations on the Missouri River during 2011 water year

8. Photograph showing overbank storage near KCP\&L Power Plant, Weston, Missouri, upstream from Kansas City, Missouri

9. Graphs showing unregulated daily mean streamflow simulated using the Missouri River Precipitation-Runoff Modeling System model as compared to measured regulated streamflows for selected locations on the Missouri River during 2011 water year

\section{Tables}

1. U.S. Geological Survey streamgages used in the Missouri River Precipitation-Runoff Modeling System model.

2. Calibrated parameters and calibration steps used in the Missouri River

Precipitation-Runoff Modeling System model

3. Statistical test results for model performance at selected U.S. Geological Survey streamgages used in the Missouri River Precipitation-Runoff Modeling System model.....

4. Maximum measured and maximum simulated daily average discharge and number of days that the National Weather Service flood category stage threshold was exceeded for selected U.S. Geological Survey streamgages and United States Army Corps of Engineers dam outflow sites. 


\section{Conversion Factors}

Inch/Pound to SI

\begin{tabular}{|c|c|c|}
\hline Multiply & By & To obtain \\
\hline \multicolumn{3}{|c|}{ Length } \\
\hline mile (mi) & 1.609 & kilometer $(\mathrm{km})$ \\
\hline \multicolumn{3}{|c|}{ Area } \\
\hline acre & 4,047 & square meter $\left(\mathrm{m}^{2}\right)$ \\
\hline acre & 0.004047 & square kilometer $\left(\mathrm{km}^{2}\right)$ \\
\hline square mile $\left(\mathrm{mi}^{2}\right)$ & 2.590 & square kilometer $\left(\mathrm{km}^{2}\right)$ \\
\hline \multicolumn{3}{|c|}{ Volume } \\
\hline cubic foot $\left(\mathrm{ft}^{3}\right)$ & 0.02832 & cubic meter $\left(\mathrm{m}^{3}\right)$ \\
\hline acre-foot (acre-ft) & 1,233 & cubic meter $\left(\mathrm{m}^{3}\right)$ \\
\hline \multicolumn{3}{|c|}{ Flow rate } \\
\hline foot per second (ft/s) & 0.3048 & meter per second $(\mathrm{m} / \mathrm{s})$ \\
\hline cubic foot per second $\left(\mathrm{ft}^{3} / \mathrm{s}\right)$ & 0.02832 & cubic meter per second $\left(\mathrm{m}^{3} / \mathrm{s}\right)$ \\
\hline
\end{tabular}

Temperature in degrees Fahrenheit $\left({ }^{\circ} \mathrm{F}\right)$ may be converted to degrees Celsius $\left({ }^{\circ} \mathrm{C}\right)$ as follows:

${ }^{\circ} \mathrm{C}=\left({ }^{\circ} \mathrm{F}-32\right) / 1.8$

Vertical coordinate information is referenced to the National Geodetic Vertical Datum of 1929 (NGVD 29).

Horizontal coordinate information is referenced to the North American Datum of 1983 (NAD 83).

Altitude, as used in this report, refers to distance above the vertical datum.

Water year, as used in this report, refers to the 12-month period October 1 through

September 30. It is designated by the calendar year in which it ends. 


\title{
The Effects of Missouri River Mainstem Reservoir System Operations on 2011 Flooding Using a Precipitation-Runoff Modeling System Model
}

\author{
By Adel E. Haj, Daniel E. Christiansen, and Roland J. Viger
}

\begin{abstract}
In 2011 the Missouri River Mainstem Reservoir System (Reservoir System) experienced the largest volume of flood waters since the initiation of record-keeping in the nineteenth century. The high levels of runoff from both snowpack and rainfall stressed the Reservoir System's capacity to control flood waters and caused massive damage and disruption along the river. The flooding and resulting damage along the Missouri River brought increased public attention to the U.S. Army Corps of Engineers (USACE) operation of the Reservoir System.
\end{abstract}

Overflow at Craig, Missouri, with Interstate 29 in the foreground, July 8, 2011. Photograph by Jeff Herzer (jeffherzer.com) and Missouri State Highway Patrol. Pilot: Sgt. Kevin G. Haywood.
To help understand the effects of Reservoir System operation on the 2011 Missouri River flood flows, the U.S. Geological Survey Precipitation-Runoff Modeling System was used to construct a model of the Missouri River Basin to simulate flows at streamgages and dam locations with the effects of Reservoir System operation (regulation) on flow removed. Statistical tests indicate that the Missouri River PrecipitationRunoff Modeling System model is a good fit for high-flow monthly and annual stream flow estimation. A comparison of simulated unregulated flows and measured regulated flows show that regulation greatly reduced spring peak flow events, consolidated two summer peak flow events to one with a markedly decreased magnitude, and maintained higher than normal base flow beyond the end of water year 2011. Further comparison of results indicate that without regulation, flows greater than those measured would have occurred and been sustained for much longer, frequently in excess of 30 days, and flooding associated with high-flow events would have been more severe. 


\section{Introduction}

The Missouri River, a tributary to the Mississippi River, drains about 529,350 $\mathrm{mi}^{2}$, approximately one-sixth of the conterminous United States, and encompasses parts of 10 States and Canada (Sprague and others, 2006) (fig. 1). The Missouri River flows through the largest reservoir system in North America. The Missouri River Mainstem Reservoir System (Reservoir System), authorized by the 1944 Flood Control Act, consists of six dams (and reservoirs) constructed on the Missouri River-Fort Peck Dam (Fort Peck Lake), Garrison Dam (Lake Sakakawea), Oahe Dam (Lake Oahe), Big Bend Dam (Lake Sharpe), Fort Randall Dam (Lake Francis Case), and Gavins Point Dam (Lewis and Clark Lake) (U.S. Army Corps of Engineers, 2006) (fig. 2). The Northwestern Division of the U.S. Army Corps of Engineers (USACE) operates the Reservoir System to manage Missouri River flows (hereafter referred to as regulation) for congressionally authorized purposes of flood control, irrigation, navigation, hydroelectric power generation, water supply, water quality, recreation, and fish and wildlife enhancement (U.S. Army Corps of Engineers, 2006). Flows in the Missouri River represent contributions from large tributary watersheds, such as the Yellowstone, the Cheyenne, the White, the Platte, the Kansas, and the Republican Rivers (fig. 2), and are affected by a wide range of climate conditions and land-use practices.

The USACE maintains records of Missouri River Basin runoff volumes dating back to 1898. In 2011 the Reservoir System experienced the largest volume of flood waters since the initiation of record-keeping. During 2011, the annual runoff into the Reservoir System (upstream of Sioux City, Iowa) was estimated at 60.8 million acre-feet (MAF). In comparison, the previous greatest annual runoff volumes were $49 \mathrm{MAF}$ in 1997 and about (roughly estimated) $50 \mathrm{MAF}$ in 1881. The Reservoir System flood-control storage allocation and floodcontrol management was patterned after the 1881 flood event, during which an estimated 40 MAF of runoff was produced during March-July. During 2011, the March-July runoff was 48.7 MAF, greatly exceeding the previous record of 36.6 MAF in 1997. The 2011 annual runoff volume of $60.8 \mathrm{MAF}$ equates to an average daily rate of about 83,980 cubic feet per second $\left(\mathrm{ft}^{3} / \mathrm{s}\right)$ over a 12-month period (Grigg and others, 2011). The high levels of runoff from both snowpack and rainfall stressed the Reservoir System's capacity to control flood waters and caused massive damage and disruption along the river (National Oceanic and Atmospheric Administration, 2011). The flooding and resulting damage during 2011 brought increased public attention to the USACE operation of the Reservoir System.

Reservoir System regulation prior to 2011 did not completely eliminate flood damages during major floods. Flood damages on the Missouri River downstream of the Reservoir System occurred in 1952, 1967, 1975, 1993, 1996, 1997, and 1999. However, in likely all cases, regulation reduced flood stages in all downstream reaches, resulting in a substantial flood-damage reduction (Grigg and others, 2011). The exception is 1952 when only Fort Peck Dam had been constructed (Grigg and others, 2011).

The 1952 flood established record flows throughout the basin and was a result of exceptional runoff from snowmelt. At the end of March, one of the heaviest snow covers on record was present on the upper Plains. In April, a peak discharge of $500,000 \mathrm{ft}^{3} / \mathrm{s}$ occurred at Bismarck, North Dakota - compared to 2011 levels of about $150,000 \mathrm{ft}^{3} / \mathrm{s}$ as a result of releases from Garrison Dam. Although peak discharges were recorded along most of the Missouri River reaches, peak flows generally decreased downstream because most of the runoff originated upstream in Montana, North Dakota, and South Dakota as a result of snowmelt (Grigg and others, 2011). Because of the mostly unregulated conditions, as well as availability of measured discharges and stages of the record high flows, the 1952 flood is useful for comparison with simulated, unregulated 2011 flows.

In order to provide a better understanding of the effects of regulation on the magnitude and duration of Missouri River flooding in 2011, the U. S. Geological Survey (USGS) constructed and calibrated a watershed model to simulate flows without the effects of regulation.

\section{Purpose and Scope}

This report documents the construction and calibration of a precipitation-runoff model of the Missouri River Basin. Model-simulated unregulated flows during the 2011 water year (October 1, 2010 through September 31, 2011) were compared with measured regulated flows during the same period to quantify the effects of regulation on flood flows. A comparison of simulated peak discharges with and without regulation is presented for selected locations along the Missouri River, from near Landusky, Montana to Saint Charles, Missouri, near the confluence of the Missouri and Mississippi Rivers (fig. 2). Simulated unregulated peak discharges for 2011 also are compared with historical peak discharges for the 1952 flood. Finally, a comparison of the duration of 2011 simulated and measured flows that exceeded National Weather Service floodstage thresholds, at selected locations, is presented.

\section{Modeling Methods and Techniques}

The Precipitation-Runoff Modeling System (PRMS) is a modular, distributed parameter, physical-process watershed model constructed to evaluate the effects of various combinations of precipitation, climate, and land use on surface-water runoff (Markstrom and others, 2008). The hydrologic system is simulated by PRMS with known physical laws and empirical relations derived from watershed characteristics (Markstrom and others, 2008), and PRMS is designed to account for 


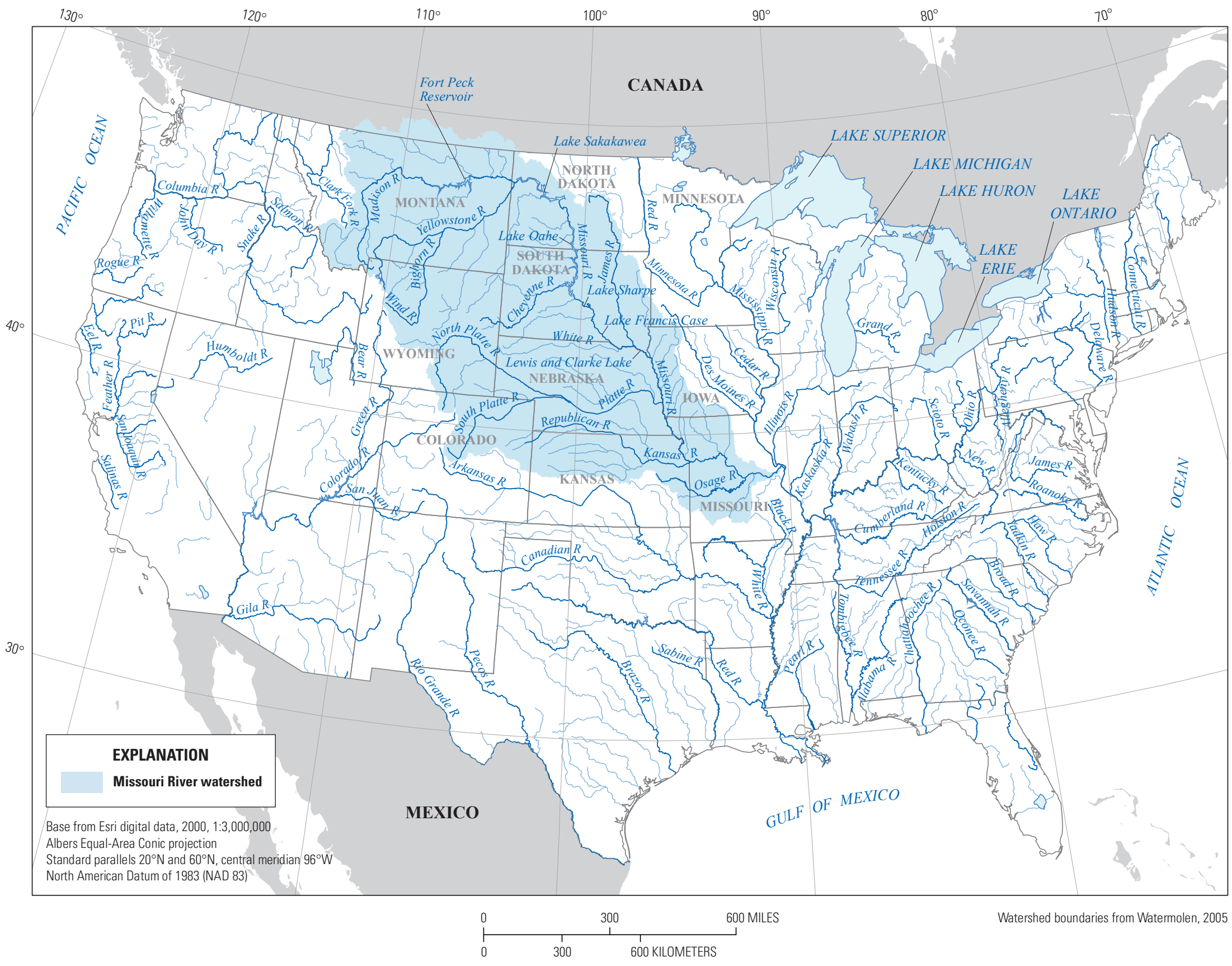

Figure 1. Location of Missouri River Basin. 


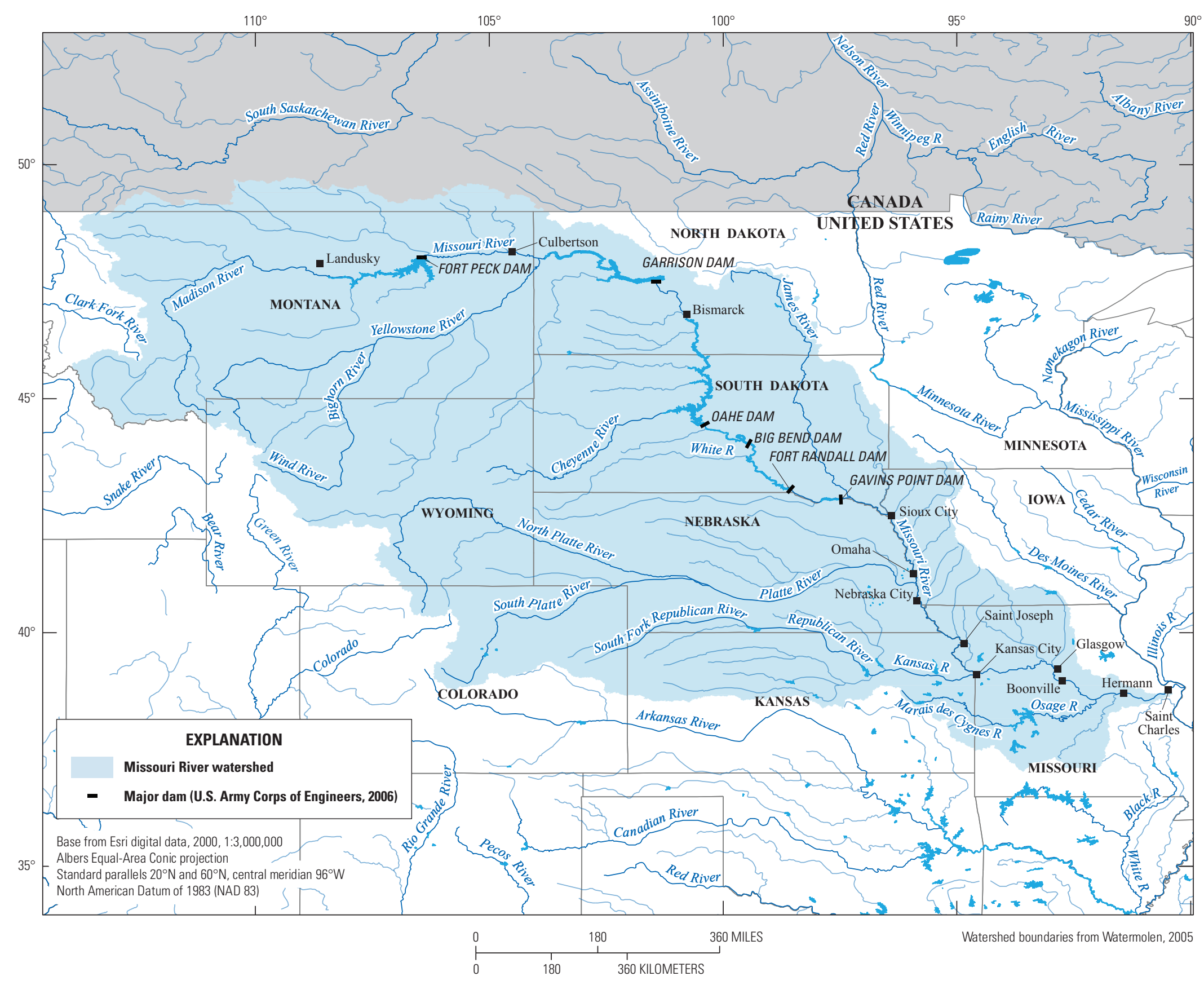

Figure 2. Location of U.S. Army Corps of Engineers (USACE) major dams along the Missouri River. 
spatially distributed watershed features and characteristics. A schematic diagram (fig. 3) shows how a typical PRMS model uses climate inputs to simulate watershed hydrology.

In PRMS, a watershed, or drainage basin (basin), is divided into a series of contiguous spatial units called hydrologic response units (HRUs) and these are based on hydrologic and physical characteristics such as land surface altitude, slope, aspect, plant type and cover, land use, soil morphology, geology, drainage boundaries, distribution of precipitation, temperature, solar radiation, and flow direction (Markstrom and others, 2008). HRUs receive and produce streamflow from and to each other, and to the drainage network consisting of stream segments (Goode and others, 2010). Each HRU is considered homogenous with respect to hydrologic and physical characteristics and to its hydrologic response. Energy and a water balance are computed by PRMS daily for each HRU (Markstrom and others, 2008).

The Missouri River PRMS model (Missouri River model) constructed for this report is a coarse-resolution model based on the Geospatial Fabric (GF) (Viger, 2012, 2014) to align with the USGS National Research Program (NRP) National Hydrologic Model specifications outlined in section "Delineation and Parameterization of Spatial Features" (Viger, 2012). The Missouri River model contains 18,897 HRUs and 9,468 stream segments and was divided at dam and streamgage locations into 16 subbasin models for calibration (figs. 4 and 5). Model calibration was completed using the Luca (Let us calibrate) software: a multiple-objective, stepwise, automated procedure for hydrologic model calibration (Hay and Umemoto, 2006).

\section{Delineation and Parameterization of Spatial Features}

For the Missouri River model, a preliminary version of the GF was used to aggregate the catchments and flow lines defined in the National Hydrography Dataset Plus dataset (NHDPlus) (Horizon Systems Corporation, 2006) into HRUs and stream segments that were relevant for modeling at the regional scale. The GF uses methods that were established in the Geographical Information Systems (GIS) Weasel software (Viger and Leavesley, 2007) to determine HRU and segment parameters. These methods are currently being revised and used to create a national database that aggregates parameters that characterize the physical features of the watersheds in the United States. This database is referred to as the GF for National Hydrologic Modeling (Viger, 2012, 2014).

Spatial features were delineated by first identifying all points of interest (POIs) on the 1:100,000 scale NHDPlus network. The POIs include USGS streamgages with a record of a guaranteed minimum quality (Falcone, 2011), the set of locations to which the National Weather Service River Forecast Centers forecast flood stage (URL accessed October 24, 2013, http://water.weather.gov/ahps/), and the set of nodes used by the USGS National Water Quality Assessment Program's SPARROW modeling project (Schwarz and others, 2006; Brown and others, 2011). The POIs also are located at where downstream NHDPlus flow lines attain a level equal to or greater than a Strahler order of 5 (Strahler, 1952) and where flow lines converge at inlets and outlets to water bodies exceeding 1 million acres. Other POIs were created to ensure the quality of the resultant network at tributary stream confluences with Strahler orders less than 5, and POIs were created where travel time (as set in NHDPlus dataset) between POIs exceeded 24 hours. In the Missouri River model, 9430 POIs were well-distributed throughout the watershed, approximately 10 miles apart. To maintain better similarity with the NHDPlus dataset, POIs were located at the downstream end of their associated NHDPlus flow lines. The slight increase in the contributing area was judged to be an acceptable source of error at this coarse scale.

Once the set of POIs was created, PRMS stream segments and HRU's were defined (fig. 4). All NHDPlus flow lines and catchments were aggregated and assigned to the nearest downstream POI, thereby aggregating all NHDPlus catchments associated with a given POI into a single feature known as a local or "incremental" contributing area (ICA). A minimal set of NHDPlus flow lines needed to sufficiently create a continuous network between all POIs was then extracted. The flow lines in this subset were aggregated to a single PRMS routing segment for each POI. The HRUs were then created by splitting the ICA using the corresponding routing segment. In the case of headwater ICAs where the segment does not fully divide the ICA, the part of the ICA below the segment headwater was split and the contributing area above the segment headwater point was associated with the smaller of the two halves. Flow was routed through PRMS stream segments using the Muskingum routing method, where routing segment length, $\mathrm{x}$, and travel time, $k$, parameters are determined from the NHDPlus flow line attributes (Markstrom, 2008).

A geospatial database was created containing parameters that characterize the physical features of the basin and the stream segments. The database contains layers generated from NHDPlus data, National Land Cover Data Base, Percent Impervious, U.S. Forest types, U.S. Forest Density, U.S. Permeability, State Soil Geographic Database (STATSGO), and general soil maps (Homer and others, 2007; U.S. Department of Agriculture, 1994; Gleeson and others, 2011; U.S. Geological Survey, 2012; Wolock, 1997). The layers were reclassified to conform to the code scheme defined in the GIS Weasel User's Manual (Viger and Leavesley, 2007). These and other data were then processed using software developed as part of this project that replicated the GIS Weasel parameterization methodologies created for PRMS, creating the final GF. The GF data were then used to characterize the physical features of the Missouri River model's HRU and segment input parameters. 


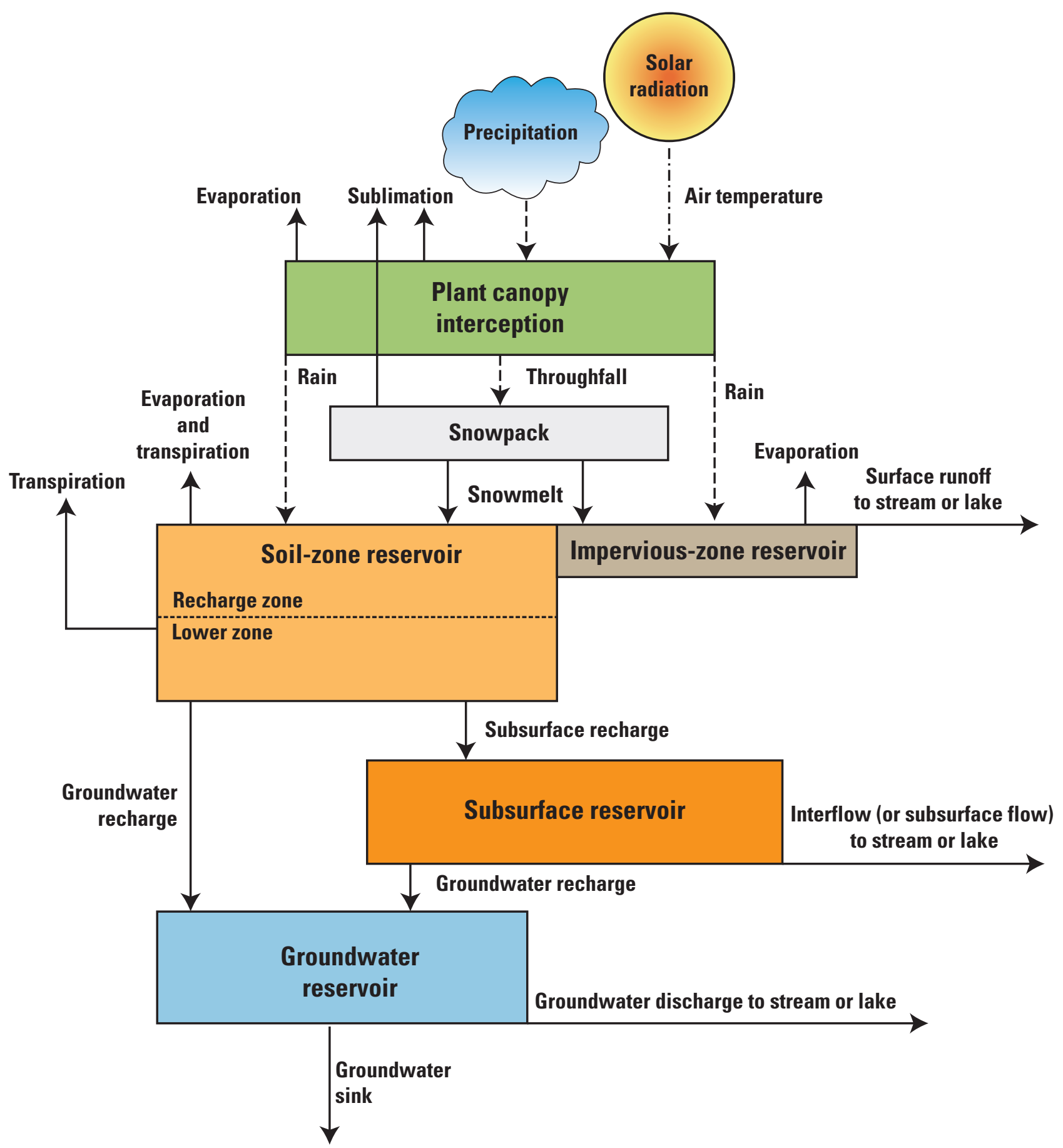

Modified from Markstrom and others, 2008

Figure 3. Schematic diagram of a watershed and its meteorological inputs (precipitation, air temperature, and solar radiation) simulated by the Precipitation-Runoff Modeling System (PRMS). 


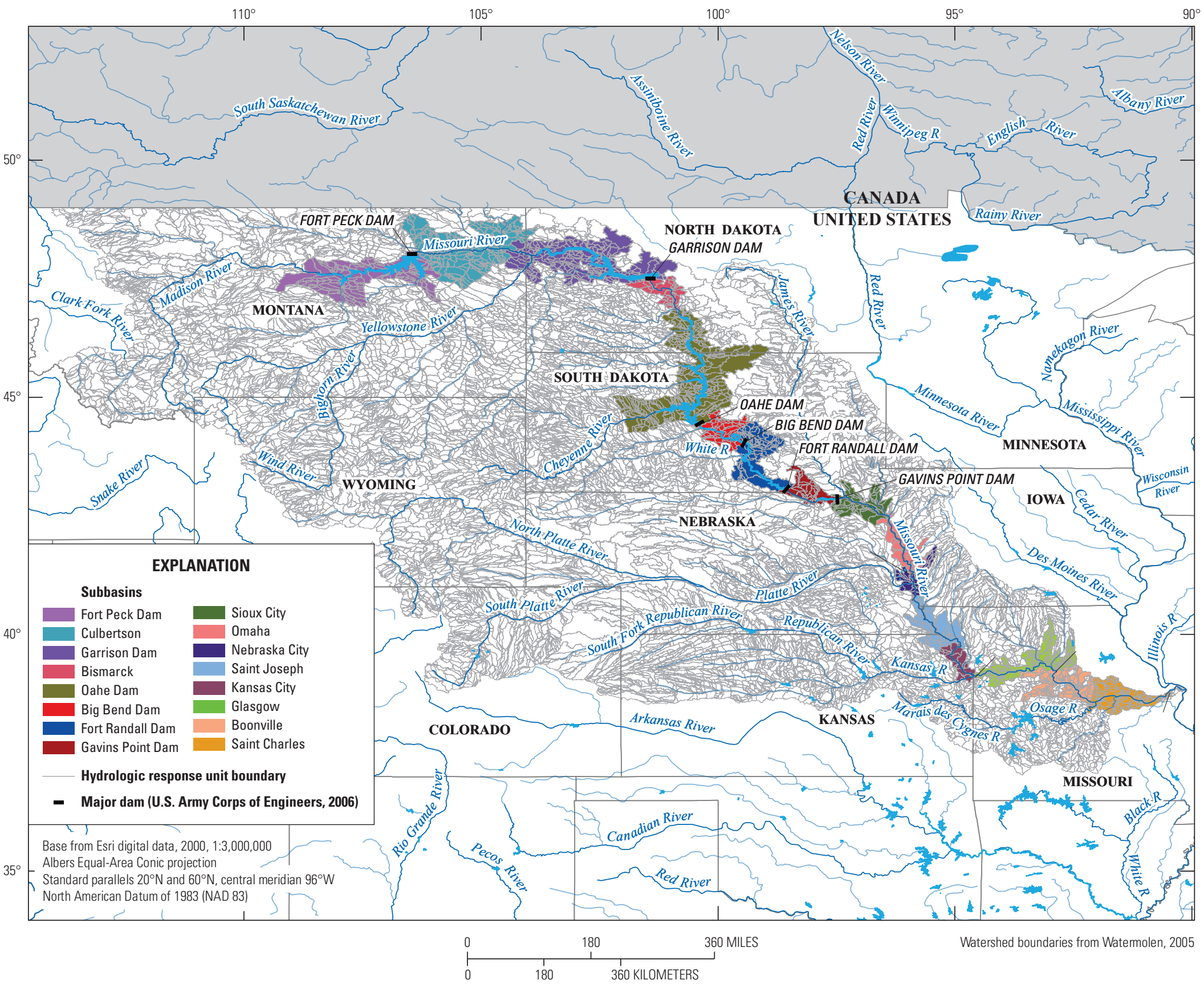

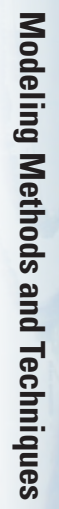

Figure 4. Subbasins and Hydrologic response units (HRUs) in the Missouri River Precipitation-Runoff Modeling System model. 


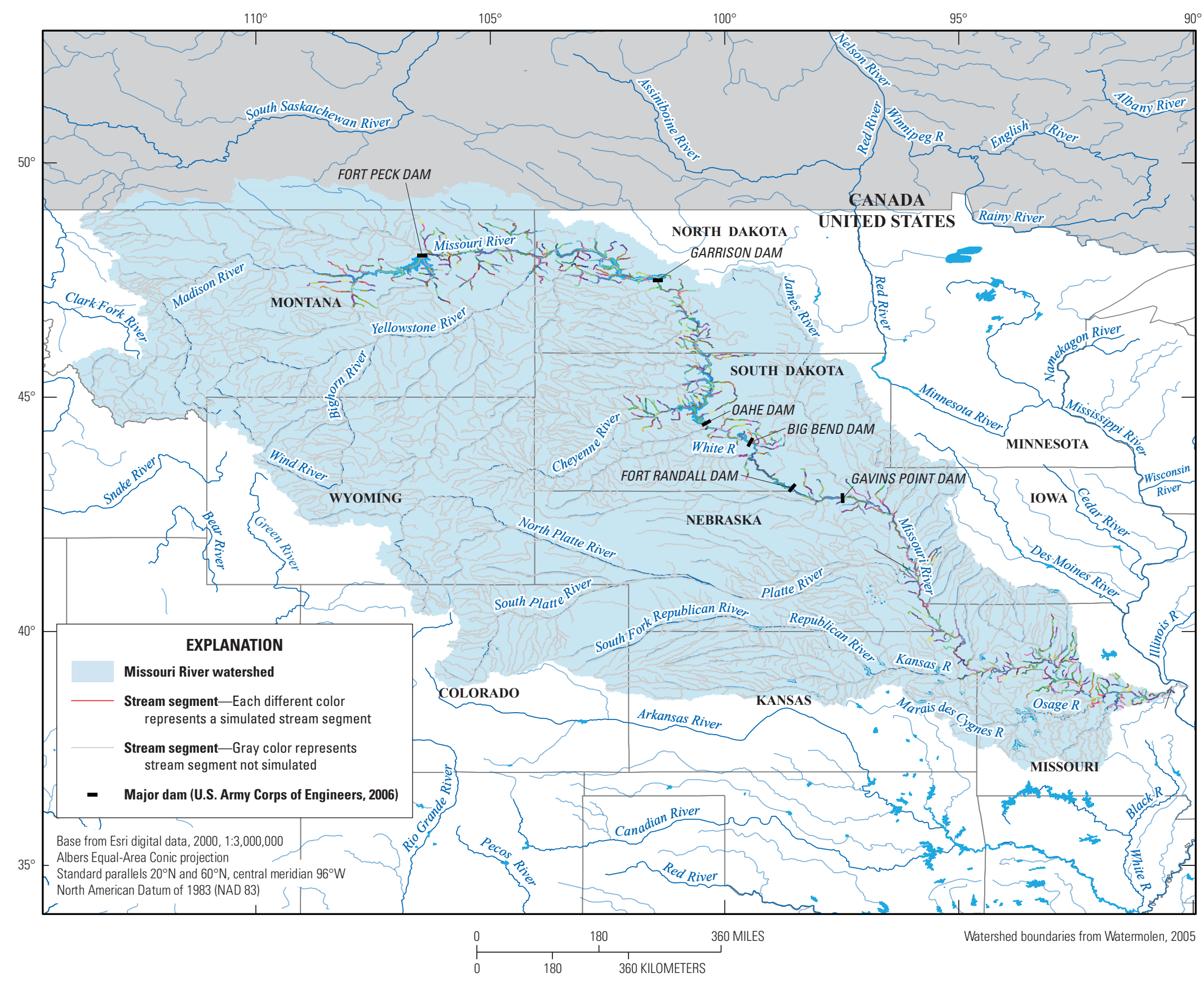




\section{Precipitation-Runoff Modeling System (PRMS) Input Data}

Precipitation, minimum temperature, and maximum temperature were used in the Missouri River model as the main climatic drivers. Daily Surface Weather and Climatological Summaries (DAYMET) were acquired (Thornton and others, 2012) for October 1, 1999 to September 30, 2011, and postprocessed by the USGS Center for Integrated Data Analytics (CIDA) to provide 12 years of input data at a 1-kilometer grid for the Missouri River model construction and calibration. DAYMET data were spatially averaged for each HRU and downloaded using the USGS geodata portal (Blodgett, 2013).

In addition to meteorological inputs, PRMS also can use streamgage data as inflow to the model. Streamgage data are especially useful where tributary inflows are affected heavily by the operation of upstream dams and reservoirs. The Missouri River model used streamgage data as input at streamgages on major tributary streams upstream from their confluence with the Missouri River for calibration and simulation to accurately account for effects of dams and reservoirs in tributary stream channels, inflows to and outflows from the Reservoir System, and flows between subbasin models. The location of 100 selected streamgages that provided model input data for historical stream flows, releases from reservoirs, tributary inflows, and measured streamflows for calibration are listed in table 1 and shown in figure 6 .

USGS streamgage data were collected using the USGS Downsizer program (Ward-Garrison and others, 2009). The Downsizer program selects, downloads, verifies, and formats streamflow, or other available time-series data, for PRMS and other environmental modeling programs. The Downsizer program accessed the USGS National Water Information System (USGS NWIS) and was used to retrieve daily streamflow measurements at 100 sites for October 1, 1999, to September 30, 2011 (U.S. Geological Survey, 2013). Daily reservoir release data also were included in the model for all Reservoir System dams for that period (U.S. Army Corps of Engineers, 2006; K. Grode, U.S. Army Corps of Engineers, written commun., 2012).

\section{Surface-Water Model Calibration}

Because of the large input datasets and extended run time of a singular model for the Missouri River Basin, the basin was divided into 16 subbasin models: Fort Peck Dam, Culbertson, Garrison Dam, Bismarck, Oahe Dam, Big Bend Dam, Fort Randall Dam, Gavins Point Dam, Sioux City, Omaha, Nebraska City, Saint Joseph, Kansas City, Glasgow, Boonville, and Saint Charles (fig. 4). Subbasin models are generally named after their calibration points, which are typically their outlets, except in the case of the Boonville subbasin model which outlets at Jefferson City, Missouri. Model calibration for parameters listed in table 2 began at the headwaters and proceeded through the basin to the confluence of the Missouri and Mississippi Rivers.

For the eight subbasin models upstream of Gavins Point Dam (Fort Peck Dam, Culbertson, Garrison Dam, Bismarck, Oahe Dam, Big Bend Dam, Fort Randall Dam, and Gavins Point Dam), each model was calibrated to naturalized flow records (U.S. Army Corps of Engineers, 2006; K. Grode, U.S. Army Corps of Engineers, written commun., 2012) at dams and at subbasin outlets (fig. 7A-H). Naturalized flow data, which represent unregulated flow, are available to the public upon request for the Missouri River at Fort Peck Garrison, Oahe, Big Bend, Fort Randall, and Gavins Point dams, at three inter-reach locations (Culbertson, Montana; Wolf Point, Montana; and Bismarck, North Dakota) and at seven locations downstream of Gavins Point Dam (Yankton, South Dakota; Sioux City, Iowa; Decatur, Nebraska; Omaha, Nebraska; Nebraska City, Nebraska, Rulo, Nebraska and Saint Joseph, Missouri). Naturalized flows were calculated by the Missouri River Basin Water Management Division (MRBWMD) of the Northwestern Division, USACE, using a legacy software program written in FORTRAN (J. Knofczynski, U.S. Army Corps of Engineers, written commun., 2014). The program used input data from fifteen U.S. Bureau of Reclamation (USBR) reservoirs; fourteen of which are located on tributaries to the Missouri River. Input data included USBR and USACE reservoir area-capacity tables, simple routing reaches, depletions for Reservoir System dams, reservoir inflows and outflows, monthly reservoir storage changes, precipitation and evaporation data for all reservoirs, and streamflow from streamgages (J. Knofczynski, U.S. Army Corps of Engineers, written commun., 2014). The eight remaining subbasin models (Sioux City, Omaha, Nebraska City, Saint Joseph, Kansas City, Glasgow, Boonville, and Saint Charles) were calibrated to measured flows (USGS streamgages: see table 1; fig. 6; fig 7I-P).

Subbasin model calibration was completed in a stepwise fashion from headwaters to the mouth, where each model was calibrated using tributary streamgage data and output from the upstream subbasin model as input, where applicable. Tributary flows upstream from inflow streamgages were not simulated in the Missouri River model (fig. 5). Climate and streamflow data for October 1, 1999, to September 30, 2011, were used to construct the model and ensure antecedent conditions were attained in the basin prior to the 2011 flood. The period of calibration was restricted to October 1, 2001 to September 30, 2011 to optimize model simulation of 2011 flows; because of the targeted application of the model, no validation period was completed. The USGS software package, Luca, was used to complete an automated, stepwise, multiple-objective calibration of climate and streamflow related parameters for each subbasin model at a daily time step (Hay and Umemoto, 2006). Emphasis was placed during calibration on matching model simulated daily streamflows with measured daily streamflows during high-flow periods. 
Table 1. U.S. Geological Survey (USGS) streamgages used in the Missouri River Precipitation-Runoff Modeling System (PRMS) model.

[USGS, U.S. Geological Survey; latitude and longitude in decimal degrees; mi² $^{2}$ square miles, NGVD 29, National Geodetic Vertical Datum of 1929; na, not available]

\begin{tabular}{|c|c|c|c|c|c|c|}
\hline $\begin{array}{c}\text { Map } \\
\text { number } \\
\text { (fig. 6) }\end{array}$ & $\begin{array}{c}\text { USGS } \\
\text { streamgage } \\
\text { number }\end{array}$ & USGS streamgage name & $\begin{array}{l}\text { Latitude } \\
\text { (north) }\end{array}$ & $\begin{array}{l}\text { Longitude } \\
\text { (west) }\end{array}$ & $\begin{array}{c}\text { Drainage area } \\
\text { measured at gage } \\
\left(\mathrm{mi}^{2}\right)\end{array}$ & $\begin{array}{c}\text { Elevation } \\
\text { (feet above } \\
\text { NGVD 29) }\end{array}$ \\
\hline 1 & 06115200 & Missouri River near Landusky, Montana & 47.631 & -108.688 & 40,987 & 7,349 \\
\hline 2 & 06130500 & Musselshell River at Mosby, Montana & 46.995 & -107.889 & 7,846 & 8,182 \\
\hline 3 & 06131000 & Big Dry Creek near Van Norman, Montana & 47.349 & -106.358 & 2,554 & 7,644 \\
\hline 4 & 06131200 & Nelson Creek near Van Norman, Montana & 47.537 & -106.153 & 100 & 7,546 \\
\hline 5 & 06132000 & Missouri River below Fort Peck Dam, Montana & 48.044 & -106.356 & 57,556 & 6,621 \\
\hline 6 & 06174500 & Milk River at Nashua, Montana & 48.130 & -106.364 & 22,332 & 6,653 \\
\hline 7 & 06177500 & Redwater River at Circle, Montana & 47.414 & -105.576 & 547 & 7,855 \\
\hline 8 & 06181000 & Poplar River near Poplar, Montana & 48.171 & -105.179 & 3,174 & 6,408 \\
\hline 9 & 06183450 & Big Muddy Creek near Antelope, Montana & 48.673 & -104.512 & 967 & 6,562 \\
\hline 10 & 06185500 & Missouri River near Culbertson, Montana ${ }^{1}$ & 48.124 & -104.473 & 88,386 & 1,883 \\
\hline 11 & 06329500 & Yellowstone River near Sidney, Montana & 47.677 & -104.155 & 69,083 & 6,172 \\
\hline 12 & 06329597 & Charbonneau Creek near Charbonneau, North Dakota & 47.851 & -103.794 & 149 & 6,529 \\
\hline 13 & 06331000 & $\begin{array}{l}\text { Little Muddy River below Cow Creek near Williston, } \\
\text { North Dakota }\end{array}$ & 48.284 & -103.573 & 875 & 6,113 \\
\hline 14 & 06332000 & White Earth River at White Earth, North Dakota & 48.376 & -102.767 & 780 & 6,791 \\
\hline 15 & 06332515 & Bear Den Creek near Mandaree, North Dakota & 47.787 & -102.769 & 74 & 6,390 \\
\hline 16 & 06332523 & East Fork Shell Creek near Parshall, North Dakota & 47.949 & -102.215 & 360 & 6,201 \\
\hline 17 & 06332770 & Deepwater Creek at mouth near Raub, North Dakota & 47.738 & -102.108 & 220 & 6,010 \\
\hline 18 & 06337000 & Little Missouri River near Watford City, North Dakota & 47.590 & -103.252 & 8,310 & 6,329 \\
\hline 19 & 06338490 & Missouri River at Garrison Dam, North Dakota & 47.502 & -101.431 & 181,400 & na \\
\hline 20 & 06339000 & Missouri River below Garrison Dam, North Dakota ${ }^{1}$ & 47.386 & -101.393 & 181,400 & 5,249 \\
\hline 21 & 06340500 & Knife River at Hazen, North Dakota & 47.285 & -101.622 & 2,240 & 5,618 \\
\hline 22 & 06341800 & Painted Woods Creek near Wilton, North Dakota & 47.275 & -100.792 & 427 & 5,790 \\
\hline 23 & 06342260 & Square Butte Creek below Center, North Dakota & 47.057 & -101.196 & 146 & 6,119 \\
\hline 24 & 06342450 & Burnt Creek near Bismarck, North Dakota & 46.915 & -100.814 & 108 & 5,538 \\
\hline 25 & 06342500 & Missouri River at Bismarck, North Dakota ${ }^{1}$ & 46.814 & -100.821 & 186,400 & 1,618 \\
\hline 26 & 06349000 & Heart River near Mandan, North Dakota & 46.834 & -100.975 & 3,310 & 5,376 \\
\hline 27 & 06349500 & Apple Creek near Menoken, North Dakota & 46.794 & -100.657 & 1,680 & 5,376 \\
\hline 28 & 06349600 & Hay Creek at Main Avenue in Bismarck, North Dakota & 46.807 & -100.734 & 31 & 5,416 \\
\hline 29 & 06354000 & Cannonball River at Breien, North Dakota & 46.376 & -100.934 & 4,100 & 5,491 \\
\hline 30 & 06354580 & Beaver Creek at Linton, North Dakota & 46.269 & -100.253 & 717 & 5,519 \\
\hline 31 & 06354882 & Oak Creek near Wakpala, South Dakota & 45.712 & -100.559 & 354 & 5,545 \\
\hline 32 & 06357800 & Grand River at Little Eagle, South Dakota & 45.658 & -100.818 & 5,322 & 5,330 \\
\hline 33 & 06360500 & Moreau River near Whitehorse, South Dakota & 45.256 & -100.843 & 4,894 & 5,451 \\
\hline 34 & 06438500 & Cheyenne River near Plainview, South Dakota & 44.529 & -101.930 & 21,425 & 6,065 \\
\hline 35 & 06439000 & Cherry Creek near Plainview, South Dakota & 44.743 & -102.054 & 1,190 & 7,080 \\
\hline 36 & 06440000 & Missouri River at Pierre, South Dakota ${ }^{1}$ & 44.373 & -100.368 & 243,500 & 4,640 \\
\hline 37 & 06441500 & Bad River near Fort Pierre, South Dakota & 44.327 & -100.384 & 3,147 & 4,684 \\
\hline 38 & 06442000 & Medicine Knoll Creek near Blunt, South Dakota & 44.563 & -99.914 & 440 & 5,286 \\
\hline 39 & 06442500 & Medicine Creek at Kennebec, South Dakota & 43.905 & -99.876 & 446 & 5,445 \\
\hline
\end{tabular}


Table 1. U.S. Geological Survey (USGS) streamgages used in the Missouri River Precipitation-Runoff Modeling System (PRMS) model.-Continued

[USGS, U.S. Geological Survey; latitude and longitude in decimal degrees; mi², square miles, NGVD29, National Geodetic Vertical Datum of 1929; na, not available]

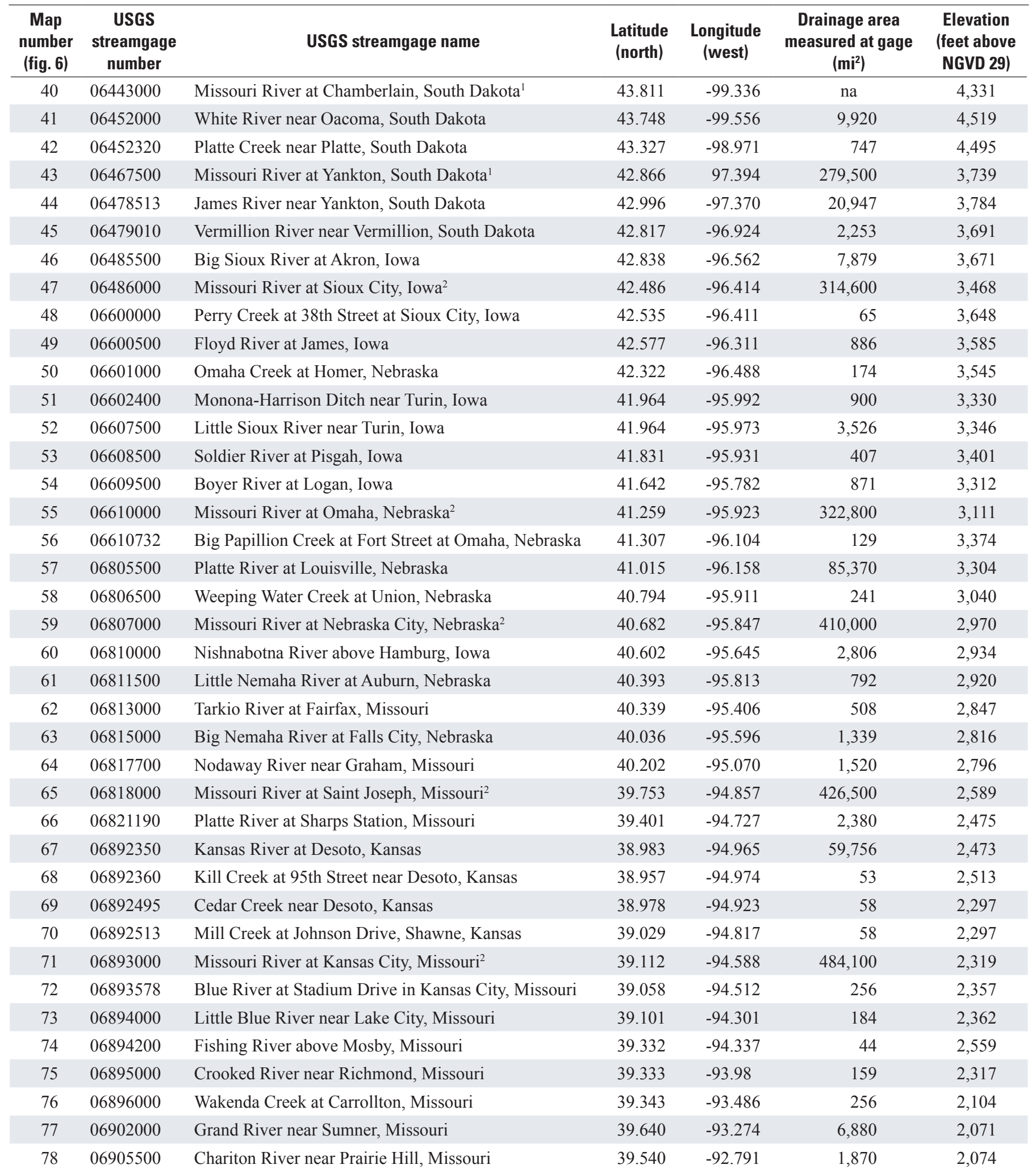


Table 1. U.S. Geological Survey (USGS) streamgages used in the Missouri River Precipitation-Runoff Modeling System (PRMS) model.-Continued

[USGS, U.S. Geological Survey; latitude and longitude in decimal degrees; mi², square miles, NGVD29, National Geodetic Vertical Datum of 1929; na, not available]

\begin{tabular}{|c|c|c|c|c|c|c|}
\hline $\begin{array}{c}\text { Map } \\
\text { number } \\
\text { (fig. 6) }\end{array}$ & $\begin{array}{c}\text { USGS } \\
\text { streamgage } \\
\text { number }\end{array}$ & USGS streamgage name & $\begin{array}{c}\text { Latitude } \\
\text { (north) }\end{array}$ & $\begin{array}{l}\text { Longitude } \\
\text { (west) }\end{array}$ & $\begin{array}{c}\text { Drainage area } \\
\text { measured at gage } \\
\left(\mathrm{mi}^{2}\right)\end{array}$ & $\begin{array}{c}\text { Elevation } \\
\text { (feet above } \\
\text { NGVD 29) }\end{array}$ \\
\hline 79 & 06906000 & Mussel Fork near Musselfork, Missouri & 39.524 & -92.950 & 267 & 2,097 \\
\hline 80 & 06906200 & East Fork Little Chariton River near Macon, Missouri & 39.751 & -92.519 & 112 & 2,433 \\
\hline 81 & 06906500 & Missouri River at Glasgow, Missouri² & 39.222 & -92.849 & 498,900 & 1,925 \\
\hline 82 & 06906800 & Lamine River near Otterville, Missouri & 38.702 & -92.979 & 543 & 2,142 \\
\hline 84 & 06909000 & Missouri River at Boonville, Missouri² & 38.980 & -92.745 & 500,700 & 1,856 \\
\hline 85 & 06909500 & Moniteau Creek near Fayette, Missouri & 39.121 & -92.567 & 75 & 1,995 \\
\hline 86 & 06909950 & Petite Saline Creek at Hwy U near Boonville, Missouri & 38.917 & -92.704 & 136 & 1,969 \\
\hline 87 & 06910230 & Hinkson Creek at Columbia, Missouri & 38.928 & -92.340 & 70 & 1,914 \\
\hline 91 & 06934000 & Gasconade River near Rich Fountain, Missouri & 38.389 & -91.820 & 3,180 & 1,817 \\
\hline 92 & 06934500 & Missouri River at Hermann, Missouri & 38.710 & -91.439 & 522,500 & 1,580 \\
\hline 93 & 06935770 & Bonhomme Creek near Clarkson Valley, Missouri & 38.658 & -90.619 & 11 & 1,474 \\
\hline 94 & 06935830 & Caulks Creek at Chesterfield, Missouri & 38.655 & -90.595 & 17 & 1,489 \\
\hline 95 & 06935890 & Creve Coeur Creek near Creve Coeur, Missouri & 38.683 & -90.489 & 22 & 1,475 \\
\hline 96 & 06935955 & Fee Fee Creek near Bridgeton, Missouri & 38.728 & -90.447 & 12 & 1,483 \\
\hline 97 & 06935965 & Missouri River at Saint Charles, Missouri ${ }^{2}$ & 38.789 & -90.471 & 524,000 & 1,357 \\
\hline 98 & 06935980 & Cowmire Creek at Bridgeton, Missouri & 38.764 & -90.433 & 4 & 1,524 \\
\hline 99 & 06935997 & Mill Creek near Florissant, Missouri & 38.848 & -90.286 & 2 & 1,418 \\
\hline
\end{tabular}

${ }^{1}$ Site used for historical streamflows.

${ }^{2}$ Site used in calibration of the Precipitation-Runoff Modeling System model. 


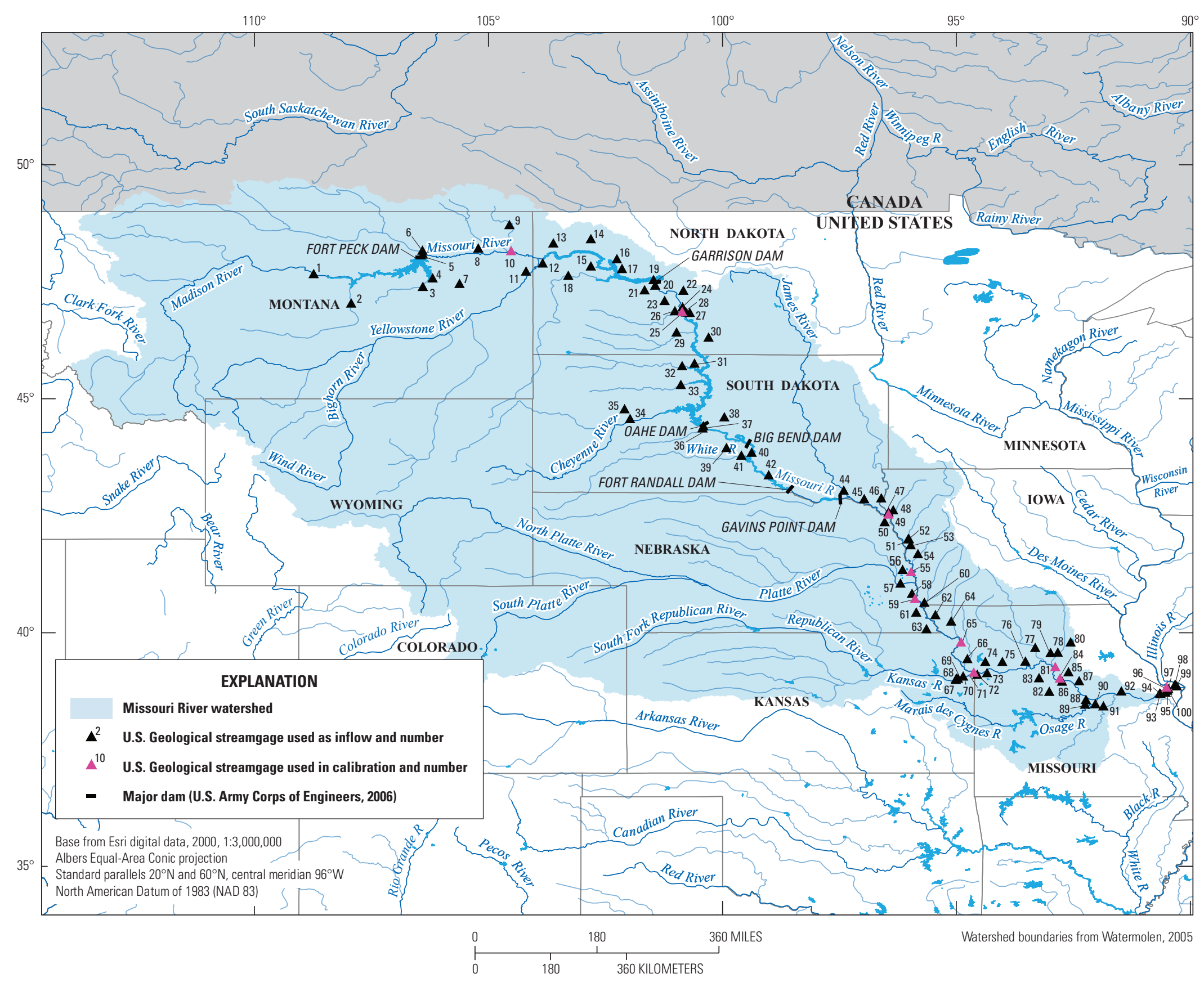

Figure 6. Location of U.S. Geological Survey (USGS) streamgages used in the Missouri River Precipitation-Runoff Modeling System (PRMS) model. 
Table 2. Calibrated parameters and calibration steps used in the Missouri River Precipitation-Runoff Modeling System (PRMS) model.

[Dimensions: nmonth, number of months $=12 ;$ nhru = number of hydrologic resposne units $($ HRUs $)=18,897$; nsegment, number of stream segments $=9,468$; F, Fahrenheit; C, Celsius, GFV, values set in Geospatial Fabric]

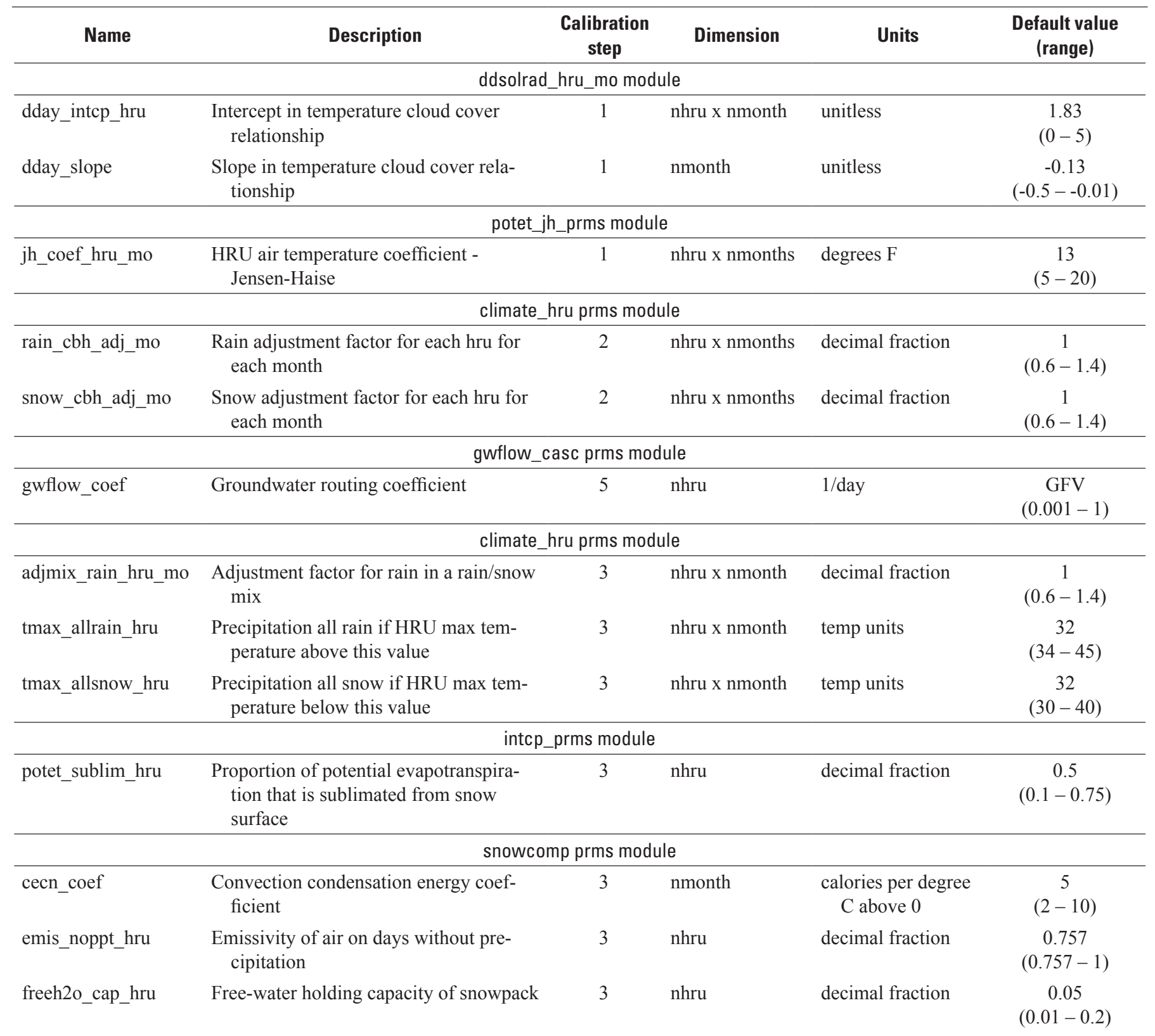


Table 2. Calibrated parameters and calibration steps used in the Missouri River Precipitation-Runoff Modeling System (PRMS) model.-Continued

[Dimensions: nmonth, number of months $=12 ;$ nhru $=$ number of hydrologic resposne units $($ HRUs $)=18,897 ;$ nsegment, number of stream segments $=9,468$; F, Fahrenheit; C, Celsius, GFV, values set in Geospatial Fabric]

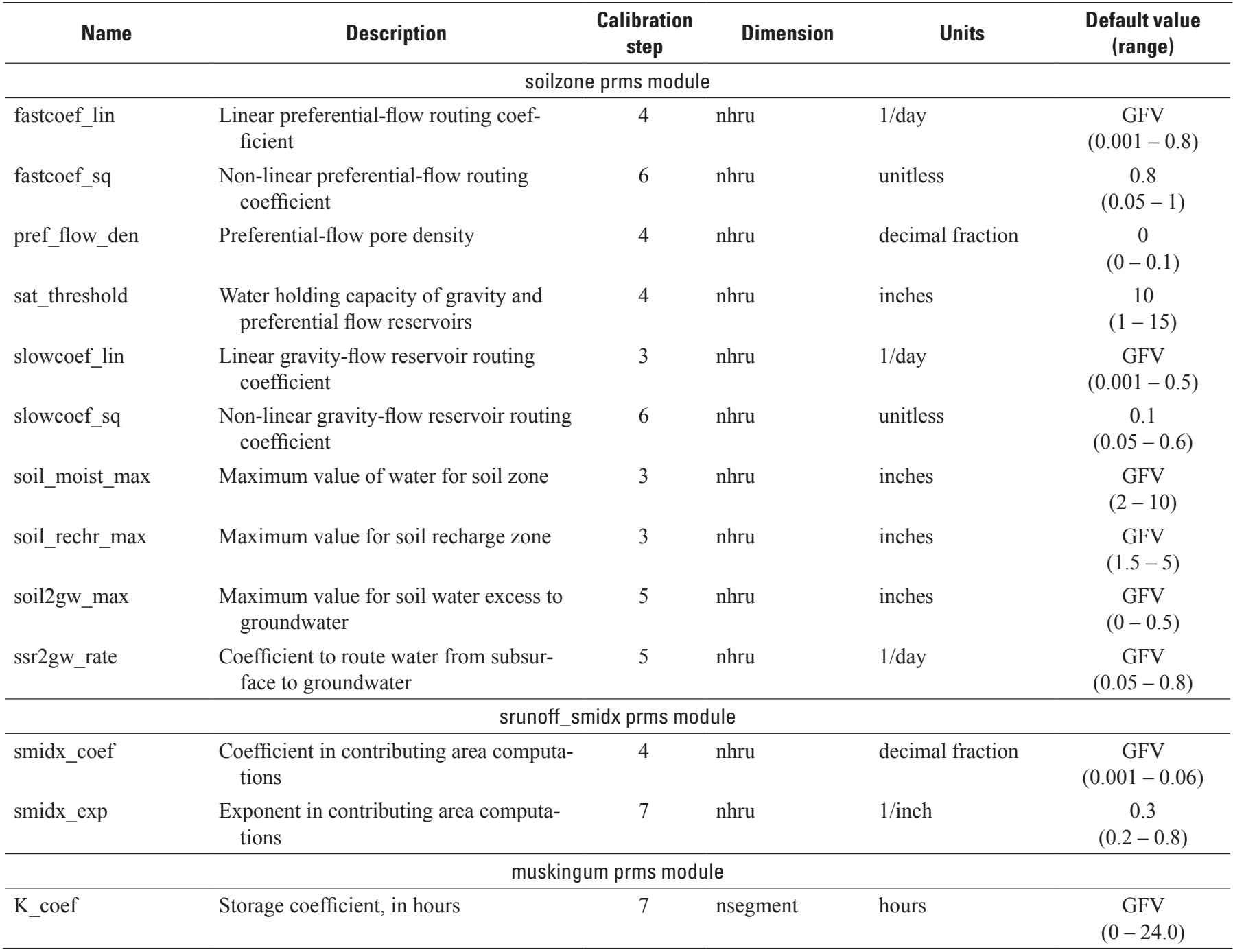



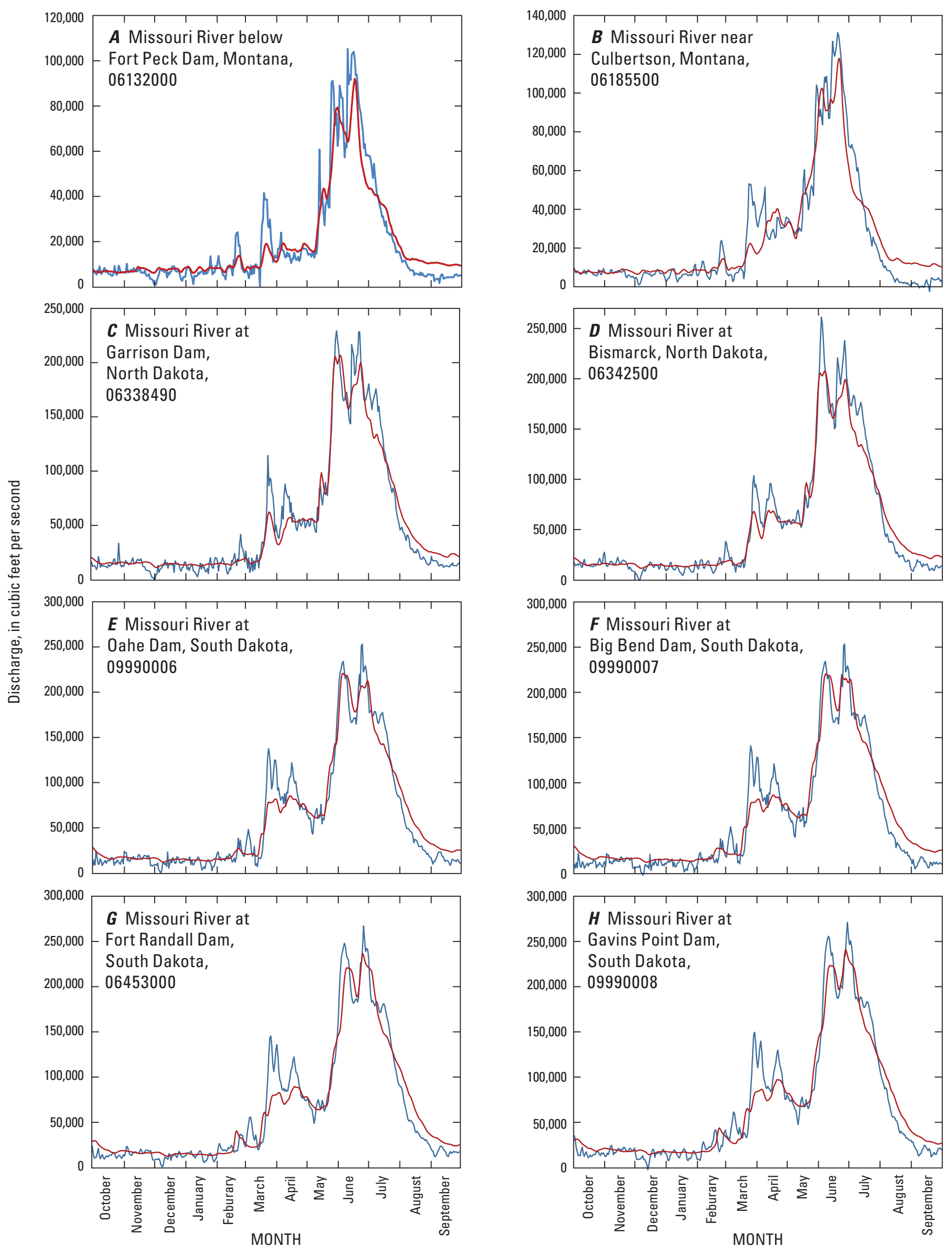

Figure 7. Daily mean streamflow simulated using the Missouri River Precipitation-Runoff Modeling

EXPLANATION System model as compared to calibration streamflow data sets $(A-H$, simulated unregulated streamflow and naturalized unregulated streamflow; $I-P$, simulated regulated streamflow and measured regulated streamflow) for selected locations on the Missouri River during 2011 water year. 

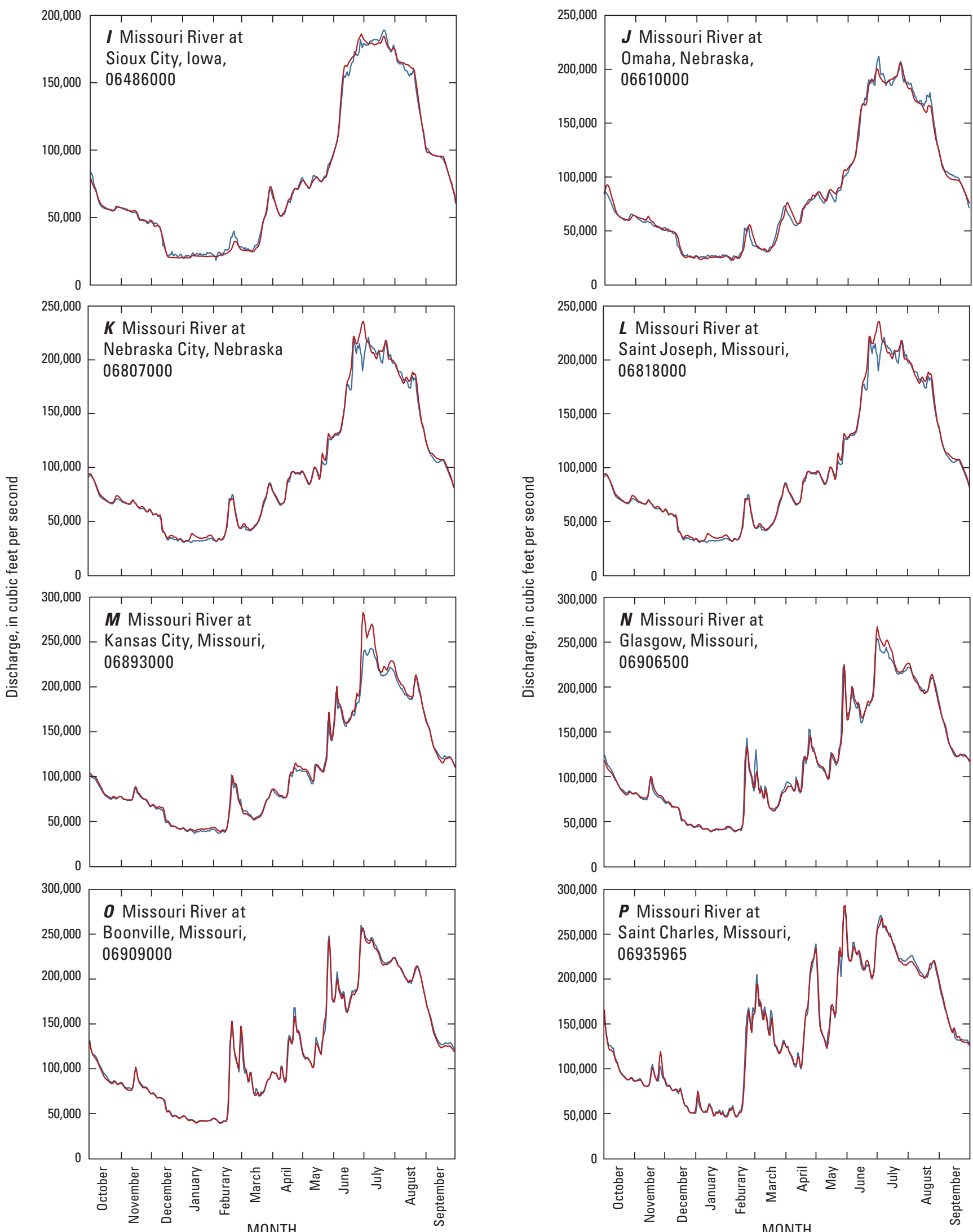

Figure 7. Daily mean streamflow simulated using the Missouri River Precipitation-Runoff Modeling System model as compared to calibration streamflow data sets $(A-H$, simulated unregulated streamflow and naturalized unregulated streamflow; $I-P$, simulated regulated streamflow and measured regulated streamflow) for selected locations on the Missouri River during 2011 water year.-Continued 


\section{Missouri River Model Performance}

Statistical tests were used to assess how well the Missouri River model simulated flow during water year 2011. The percent bias $(P B I A S)$, root mean square error-observation standard deviation ratio $(R S R)$, Nash Sutcliffe efficiency $(N S E)$, and coefficient of determination $\left(R^{2}\right)$ statistics (Moriasi and others, 2007; Singh and others, 2004; Nash and Sutcliffe, 1970) were used to evaluate model performance.

The PBIAS measures the average tendency of the simulated data to be larger or smaller than their observed counterparts (Gupta and others, 1999). A PBIAS value of 0.0 indicates ideal performance, whereas positive values indicate underestimation bias and negative values indicate overestimation bias (Moriasi and others, 2007). Model streamflow simulation is considered "very good" if the PBIAS is between 0 and plus or minus $( \pm) 10$ percent, "good" if the PBIAS is between \pm 10 and \pm 15 percent, "satisfactory" if the $P B I A S$ is between \pm 15 and \pm 25 percent, and "unsatisfactory" if the PBIAS is \pm 25 percent and greater (Moraisi and others, 2007).

The $R S R$ was developed to use the standard deviation of observations to qualify what is considered a low root mean square error for model performance (Singh and others, 2004). The $R S R$ incorporates the benefits of error index statistics and includes a normalization/scaling factor. The $R S R$ ranges from 0 , which is an optimal value, to a large positive value, which means a poor fit (Singh and others, 2004). If $R S R$ is between 0 and 0.5 then performance was "very good", if $R S R$ is between 0.5 and 0.6 then performance was "good", $R S R$ between 0.6 and 0.7 is "satisfactory", and $R S R$ greater than 0.7 is "unsatisfactory" (Moriasi and others, 2007).

The NSE is a normalized statistic that provides a measure of how well simulated values match measured datasets. The $N S E$ values range from $-\infty$ to 1 . Values less than 0 indicate that the mean measured streamflow is a better predictor than simulated streamflows. A value of 0.0 indicates the simulated streamflow is as good as using the average value of all the measured data, and a value of 1 indicates a perfect fit between measured and simulated values. Moriasi and others (2007) suggest that a NSE of greater than 0.50 is satisfactory for streamflows simulated using models such as PRMS.

The $R^{2}$ evaluates how accurately the simulated model results track the variability in the measured data that is explained by the simulated output. The $R^{2}$ can reveal the strength of the linear relation between the predicted and the measured values. It can range between 0 and 1 , and the closer the value is to 1 the better the linear correlation between simulated and measured values (Kalin and Hantush, 2006). For hydrologic modeling, values above 0.5 are considered to be satisfactory (Gassman and others, 2007).
The statistics PBIAS, RSR, NSE, and $R^{2}$ are defined as:

$$
\begin{gathered}
\text { PBIAS }=\left[\frac{\sum_{i=1}^{n}\left(Q_{o b s, i}-Q_{\text {sim }, i}\right)}{\sum_{i=1}^{n}\left(Q_{o b s, i}\right)}\right] * 100 \\
R S R=\frac{R S M E}{S T D E V_{o b s}}=\frac{\left[\sqrt{\sum_{i=0}^{n}\left(Q_{o b s, i}-Q_{s i m, i}\right)}\right]}{\left[\sqrt{\sum_{i=0}^{n}\left(Q_{o b s, i}-\bar{Q}_{o b s, i}\right)^{2}}\right]} \\
N S E=1-\left[\frac{\sum_{i=1}^{n}\left(Q_{o b s, i}-Q_{\text {sim }, i}\right)^{2}}{\sum_{i=1}^{n}\left(Q_{o b s, i}-\bar{Q}_{o b s, i}\right)^{2}}\right] \\
\left.R^{2}=\frac{\left[\sum_{i=0}^{n}\left(Q_{o b s, i}-\bar{Q}_{o b s, i}\right)\left(Q_{s i m, i}-\bar{Q}_{s i m, i}\right)\right]^{2}}{\left[\sum_{i=0}^{n}\left(Q_{o b s, i}-\bar{Q}_{o b s, i}\right)^{2}\right.}\right]\left[\sum_{i=0}^{n}\left(Q_{s i m, i}-\bar{Q}_{\text {sim }, i}\right)^{2}\right]
\end{gathered}
$$

where

$Q_{o b s, i} \quad$ is the $i$ th measurement for basin streamflow,

$Q_{\text {sim }, i} \quad$ is the $i$ th simulated basin streamflow,

$\bar{Q}_{o b s, i} \quad$ is the mean of the measured basin streamflow,

$\bar{Q}_{\text {sim }, i} \quad$ is the mean of the simulated basin streamflow,

RMSE is the root mean square error,

$S T D E V_{\text {obs }}$ is the standard deviation of the observations, and

$n \quad$ is the total number of measurements.

Simulated regulated flows from the Missouri River model were evaluated at nine subbasin calibration points: Bismarck, North Dakota; Sioux City, Iowa; Omaha, Nebraska; Nebraska City, Nebraska; Saint Joseph, Missouri; Kansas City, Missouri; Glasgow, Missouri; Boonville, Missouri; and Saint Charles, Missouri, for the 2011 water year (table 1; fig. 2). The $P B I A S, R S R, N S E$, and $R^{2}$ monthly and annual values for the 2011 water year are listed for each of these calibration sites (table 3). Based on statistical results, the Missouri River model is a good fit for annual streamflow estimation at all locations, with $P B I A S$ and $R S R$ ratings of very good and NSE and $R^{2}$ ratings of satisfactory. Monthly statistics indicate a few unsatisfactory ratings, in particular, the months of January and July. These ratings, explained in detail below, may be attributed to the selected model calibration method (January), and the simplified approach for model construction (July). 
The Missouri River model was calibrated with emphasis placed on the peak flow timing and volumes during high-flow months (April-August), and less emphasis during low-flow months (September-March), and, because of this, simulated flow peak timing and volumes during low-flow months may be less accurate. This may explain the unsatisfactory ratings of the model for January, as well as other low-flow months. Further calibration of the Missouri River model would likely improve simulations during low-flow months.

During the high-flow months of 2011, levees were breached and overtopped and, as a result, a large portion of flow through the adjacent channel was directed into the floodplain. The Missouri River model was not constructed to simulate this process of overbank storage, and therefore the model will overestimate flow downstream from an overtopping event. This phenomenon had taken place at many locations along the river, but was most pronounced in July 2011 at Kansas City, Missouri where upstream flooding directed a large portion of flow into the floodplain (fig. 8). Unsatisfactory ratings in calibration statistics for July are associated with these overbank storage events. Since the PRMS "does not account for overbank storage which occurs during high flood events" (R.S. Regan, U.S. Geological Survey, written commun., 2013), the statistical tests for months where these events occur are invalid, and may be omitted from results. Moreover, the model was designed to accurately simulate flows in the Missouri River without the effects of Reservoir System regulation, which includes the constructed and managed levees in the Missouri River floodplain.

\section{The Effects of Missouri River Mainstem Reservoir System Operations on 2011 Flooding}

Determining the effects of regulation on 2011 flows was accomplished by: (1) performing model simulations of Missouri River flows that excluded the storage and routing operations of the Reservoir System; and (2) comparing modelsimulated unregulated flow conditions (peaks and duration of high flows) to measured regulated flow conditions during 2011. The Missouri River model simulation began with the most upstream (Fort Peck Dam) subbasin model. Simulated flows at Fort Peck Dam were then routed as inflow to the next downstream subbasin model. This process was continued stepwise through the basin to the confluence of the Missouri River and Mississippi River. Hydrographs of simulated unregulated

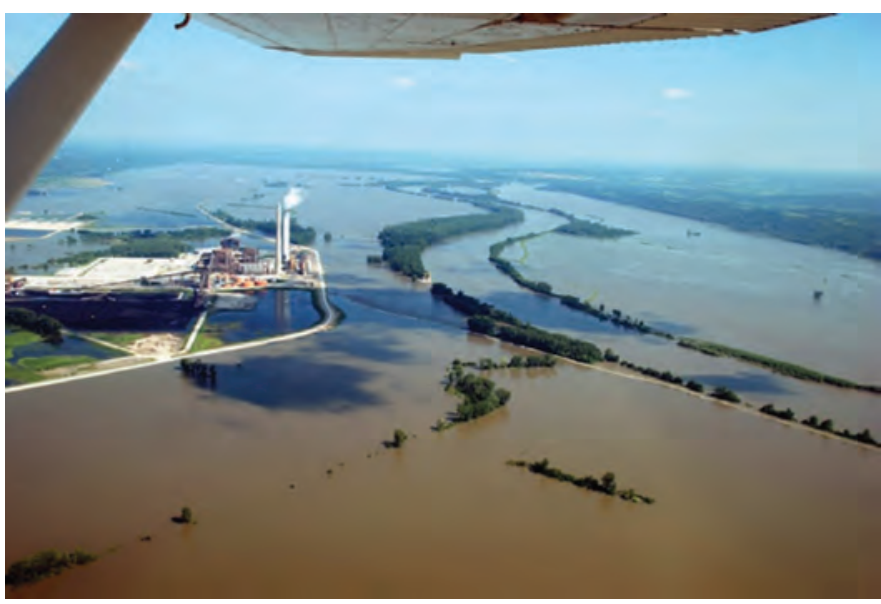

Figure 8. Overbank storage near KCP\&L Power Plant, Weston, Missouri, upstream from Kansas City, Missouri (streamgage 06893000). View to south photographed on July 8, 2011. Photograph by Jeff Herzer (jeffherzer.com). Aircraft: Missouri State Highway Patrol, Sgt. Kevin G. Haywood, pilot.

flows and measured regulated flows are presented for dam and selected streamgage locations on the Missouri River: Fort Peck Dam, Montana; Culbertson, Montana; Garrison Dam, North Dakota; Bismarck, North Dakota; Oahe Dam, South Dakota; Big Bend Dam, South Dakota; Fort Randall Dam, South Dakota; Gavins Point Dam, South Dakota; Sioux City, Iowa; Omaha, Nebraska; Nebraska City, Nebraska; Saint Joseph, Missouri; Boonville, Missouri; Kansas City, Missouri; Glasgow, Missouri; Boonville, Missouri; and Saint Charles, Missouri (fig. 9). Hydrographs plot average daily discharge values for measured and simulated flows in cubic feet per second $\left(\mathrm{ft}^{3} / \mathrm{s}\right)$.

\section{Comparison of Simulated (Unregulated) Flows and Measured (Regulated) Flows}

Simulated daily average discharge (SDAD) and measured daily average discharge (MDAD) values, maximum SDAD and MDAD values, and spring and summer SDAD and MDAD peak flow values, are compared directly (magnitude comparison). Spring SDAD and MDAD peak flows are those peak flows that were either simulated or measured in February, March, and April, whereas summer SDAD and MDAD peak flows are those that were either simulated or measured in May, June, and July. 
Table 3. Statistical test results for model performance at selected U.S. Geological Survey (USGS) streamgages used in the Missouri River Precipitation-Runoff Modeling System (PRMS) model.

[Water year (October 1, 2010 through September 31, 2011); PBIAS, percent bias; RSR, root mean square error-observation standard deviation ratio; NSE, Nash and Sutcliffe coefficient of efficiency; $R^{2}$, coefficient of determination]

\begin{tabular}{|c|c|c|c|c|c|c|c|c|c|c|c|c|c|}
\hline \multicolumn{14}{|c|}{ Water year and monthly statistics } \\
\hline Statistic & WY & October & November & December & January & Feburary & March & April & May & June & July & August & September \\
\hline \multicolumn{14}{|c|}{06342500 Missouri River at Bismarck, North Dakota } \\
\hline PBIAS & 1.20 & 3.80 & 2.40 & 2.40 & 6.30 & 6.60 & -2.30 & -8.60 & 5.20 & 2.40 & 0.500 & -1.80 & -1.10 \\
\hline$R S R$ & 0.0653 & 0.949 & 0.218 & 0.456 & 0.774 & 6.77 & 0.820 & 0.654 & 0.178 & 0.316 & 0.257 & 0.208 & 0.114 \\
\hline NSE & 0.996 & 0.0691 & 0.951 & 0.785 & 0.382 & -46.5 & 0.305 & 0.558 & 0.967 & 0.896 & 0.932 & 0.956 & 0.987 \\
\hline$R^{2}$ & 0.996 & 0.824 & 0.991 & 0.868 & 0.999 & 0.728 & 0.327 & 0.881 & 0.986 & 0.965 & 0.939 & 0.980 & 0.992 \\
\hline \multicolumn{14}{|c|}{06486000 Missouri River at Sioux City, lowa } \\
\hline PBIAS & 0.100 & 0.500 & -0.400 & 2.80 & 6.10 & 9.00 & 1.90 & -0.400 & 1.10 & -3.00 & 1.00 & -1.80 & -0.100 \\
\hline$R S R$ & 0.0522 & 0.221 & 0.205 & 0.190 & 1.40 & 0.668 & 0.142 & 0.153 & 0.218 & 0.227 & 0.730 & 0.184 & 0.0996 \\
\hline NSE & 0.997 & 0.949 & 0.957 & 0.963 & -1.02 & 0.538 & 0.979 & 0.976 & 0.951 & 0.947 & 0.450 & 0.965 & 0.990 \\
\hline$R^{2}$ & 0.998 & 0.981 & 0.960 & 0.973 & 0.457 & 0.791 & 0.992 & 0.981 & 0.974 & 0.985 & 0.687 & 0.988 & 0.991 \\
\hline \multicolumn{14}{|c|}{06610000 Missouri River at Omaha, Nebraska } \\
\hline PBIAS & -0.100 & -3.10 & -2.60 & -2.40 & 4.60 & -1.30 & 4.90 & -3.30 & -3.60 & -0.400 & 0.300 & 2.80 & 1.30 \\
\hline$R S R$ & 0.0753 & 0.498 & 0.666 & 0.251 & 1.94 & 0.544 & 0.284 & 0.508 & 0.526 & 0.129 & 0.715 & 0.344 & 0.235 \\
\hline NSE & 0.994 & 0.744 & 0.541 & 0.935 & -2.91 & 0.693 & 0.917 & 0.733 & 0.714 & 0.983 & 0.471 & 0.877 & 0.943 \\
\hline$R^{2}$ & 0.994 & 0.937 & 0.848 & 0.952 & 0.115 & 0.745 & 0.958 & 0.791 & 0.887 & 0.984 & 0.490 & 0.957 & 0.965 \\
\hline \multicolumn{14}{|c|}{06807000 Missouri River at Nebraska City, Nebraska } \\
\hline PBIAS & -1.90 & -1.70 & -0.800 & -2.70 & -8.40 & -0.100 & -2.30 & -0.900 & -1.50 & -3.80 & -1.60 & -1.00 & -1.60 \\
\hline$R S R$ & 0.0892 & 0.168 & 0.267 & 0.142 & 3.37 & 0.129 & 0.114 & 0.111 & 0.323 & 0.285 & 1.68 & 0.246 & 0.185 \\
\hline NSE & 0.992 & 0.971 & 0.927 & 0.979 & -10.7 & 0.983 & 0.987 & 0.987 & 0.892 & 0.916 & -1.93 & 0.938 & 0.965 \\
\hline$R^{2}$ & 0.994 & 0.992 & 0.956 & 0.993 & 0.142 & 0.985 & 0.995 & 0.992 & 0.956 & 0.971 & 0.00 & 0.948 & 0.989 \\
\hline \multicolumn{14}{|c|}{06818000 Missouri River at Saint Joseph, Missouri } \\
\hline PBIAS & 2.20 & 0.700 & 2.30 & 1.60 & 9.70 & 6.20 & 3.80 & 1.40 & 2.00 & -4.90 & 6.50 & 0.400 & 3.20 \\
\hline$R S R$ & 0.151 & 0.284 & 0.604 & 0.352 & 3.78 & 0.519 & 0.367 & 0.464 & 0.486 & 0.445 & 1.15 & 0.401 & 0.306 \\
\hline NSE & 0.977 & 0.917 & 0.623 & 0.872 & -13.7 & 0.721 & 0.861 & 0.778 & 0.756 & 0.796 & -0.366 & 0.834 & 0.903 \\
\hline$R^{2}$ & 0.979 & 0.964 & 0.794 & 0.905 & 0.502 & 0.765 & 0.910 & 0.790 & 0.792 & 0.837 & 0.382 & 0.865 & 0.972 \\
\hline \multicolumn{14}{|c|}{06893000 Missouri River at Kansas City, Missouri } \\
\hline PBIAS & -2.20 & -1.80 & -0.600 & -2.60 & -4.50 & -1.70 & 2.30 & -2.20 & -0.500 & -3.90 & -6.00 & -1.60 & 1.30 \\
\hline$R S R$ & 0.120 & 0.185 & 0.235 & 0.188 & 1.48 & 0.190 & 0.195 & 0.233 & 0.282 & 0.893 & 1.50 & 0.359 & 0.164 \\
\hline$N S E$ & 0.986 & 0.965 & 0.943 & 0.964 & -1.26 & 0.963 & 0.961 & 0.944 & 0.918 & 0.175 & -1.34 & 0.867 & 0.972 \\
\hline$R^{2}$ & 0.991 & 0.997 & 0.953 & 0.986 & 0.633 & 0.964 & 0.992 & 0.978 & 0.920 & 0.907 & 0.944 & 0.982 & 0.988 \\
\hline
\end{tabular}


Table 3. Statistical test results for model performance at selected U.S. Geological Survey (USGS) streamgages used in the Missouri River Precipitation-Runoff Modeling System (PRMS) model.-Continued

[Water year (October 1, 2010 through September 31, 2011); PBIAS, percent bias; RSR, root mean square error-observation standard deviation ratio; NSE, Nash and Sutcliffe coefficient of efficiency; $R^{2}$, coefficient of determination]

\begin{tabular}{|c|c|c|c|c|c|c|c|c|c|c|c|c|c|}
\hline \multicolumn{14}{|c|}{ Water year and monthly statistics } \\
\hline \multicolumn{14}{|c|}{06906500 Missouri River at Glasgow, Missouri } \\
\hline PBIAS & 0.00 & 2.20 & -2.60 & -1.50 & -1.70 & 2.80 & 3.50 & 2.20 & 1.70 & -0.800 & -3.00 & 0.500 & -0.400 \\
\hline$R S R$ & 0.0895 & 0.203 & 0.446 & 0.127 & 0.571 & 0.250 & 0.413 & 0.278 & 0.256 & 0.249 & 0.675 & 0.303 & 0.101 \\
\hline NSE & 0.992 & 0.958 & 0.794 & 0.983 & 0.663 & 0.935 & 0.823 & 0.920 & 0.933 & 0.936 & 0.529 & 0.905 & 0.990 \\
\hline$R^{2}$ & 0.992 & 0.992 & 0.911 & 0.991 & 0.948 & 0.940 & 0.883 & 0.933 & 0.940 & 0.942 & 0.972 & 0.959 & 0.991 \\
\hline \multicolumn{14}{|c|}{06909000 Missouri River at Boonville, Missouri } \\
\hline PBIAS & 0.800 & 1.60 & 1.40 & 1.20 & 0.900 & -0.100 & -1.20 & 1.90 & 0.200 & 1.40 & 1.00 & -0.200 & 1.90 \\
\hline$R S R$ & 0.0487 & 0.145 & 0.208 & 0.0906 & 0.309 & 0.0759 & 0.234 & 0.185 & 0.110 & 0.177 & 0.221 & 0.130 & 0.172 \\
\hline NSE & 0.998 & 0.978 & 0.955 & 0.992 & 0.901 & 0.994 & 0.943 & 0.965 & 0.987 & 0.968 & 0.950 & 0.983 & 0.969 \\
\hline$R^{2}$ & 0.998 & 0.992 & 0.988 & 0.996 & 0.959 & 0.994 & 0.972 & 0.975 & 0.988 & 0.982 & 0.989 & 0.986 & 0.999 \\
\hline \multicolumn{14}{|c|}{06935965 Missouri River at Saint Charles, Missouri } \\
\hline PBIAS & 0.300 & 0.900 & -2.00 & -0.600 & -0.400 & 4.90 & 1.50 & -0.600 & -0.900 & -0.200 & 1.00 & 0.600 & -0.500 \\
\hline$R S R$ & 0.0697 & 0.119 & 0.801 & 0.108 & 0.549 & 0.146 & 0.244 & 0.0758 & 0.151 & 0.297 & 0.221 & 0.448 & 0.174 \\
\hline$N S E$ & 0.995 & 0.985 & 0.336 & 0.988 & 0.688 & 0.978 & 0.939 & 0.994 & 0.976 & 0.909 & 0.950 & 0.792 & 0.969 \\
\hline$R^{2}$ & 0.995 & 0.988 & 0.741 & 0.989 & 0.892 & 0.988 & 0.949 & 0.995 & 0.982 & 0.912 & 0.972 & 0.823 & 0.977 \\
\hline
\end{tabular}



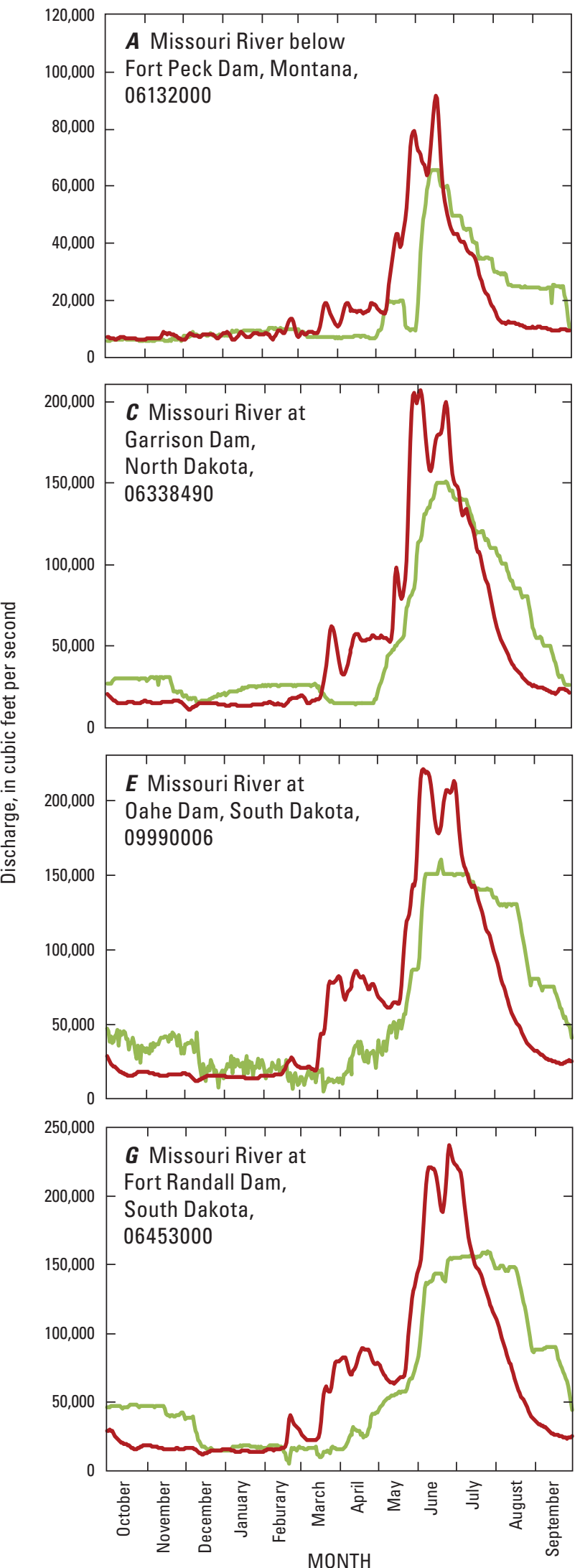

Figure 9. Unregulated daily mean streamflow simulated using the Missouri River Precipitation-Runoff Modeling System model as compared to measured regulated streamflows for selected locations on the Missouri River during 2011 water year.
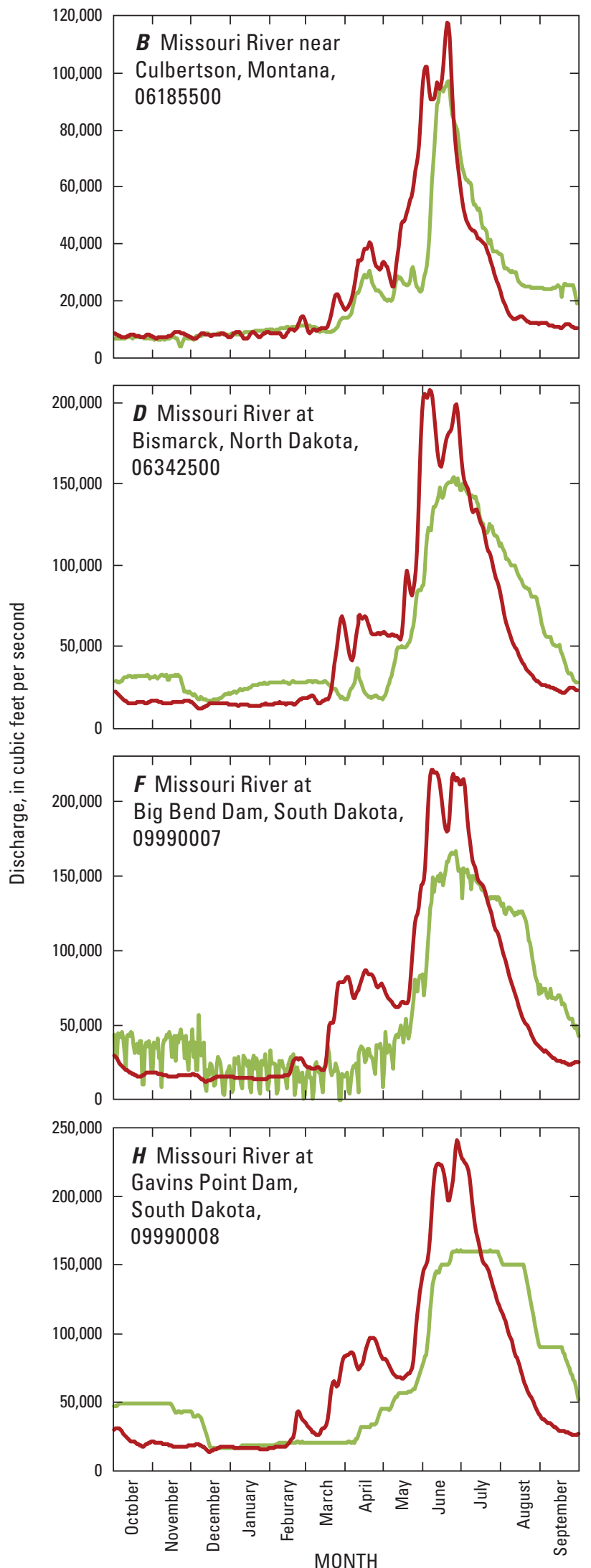

EXPLANATION

Simulated unregulated streamflow Observed regulated streamflow 

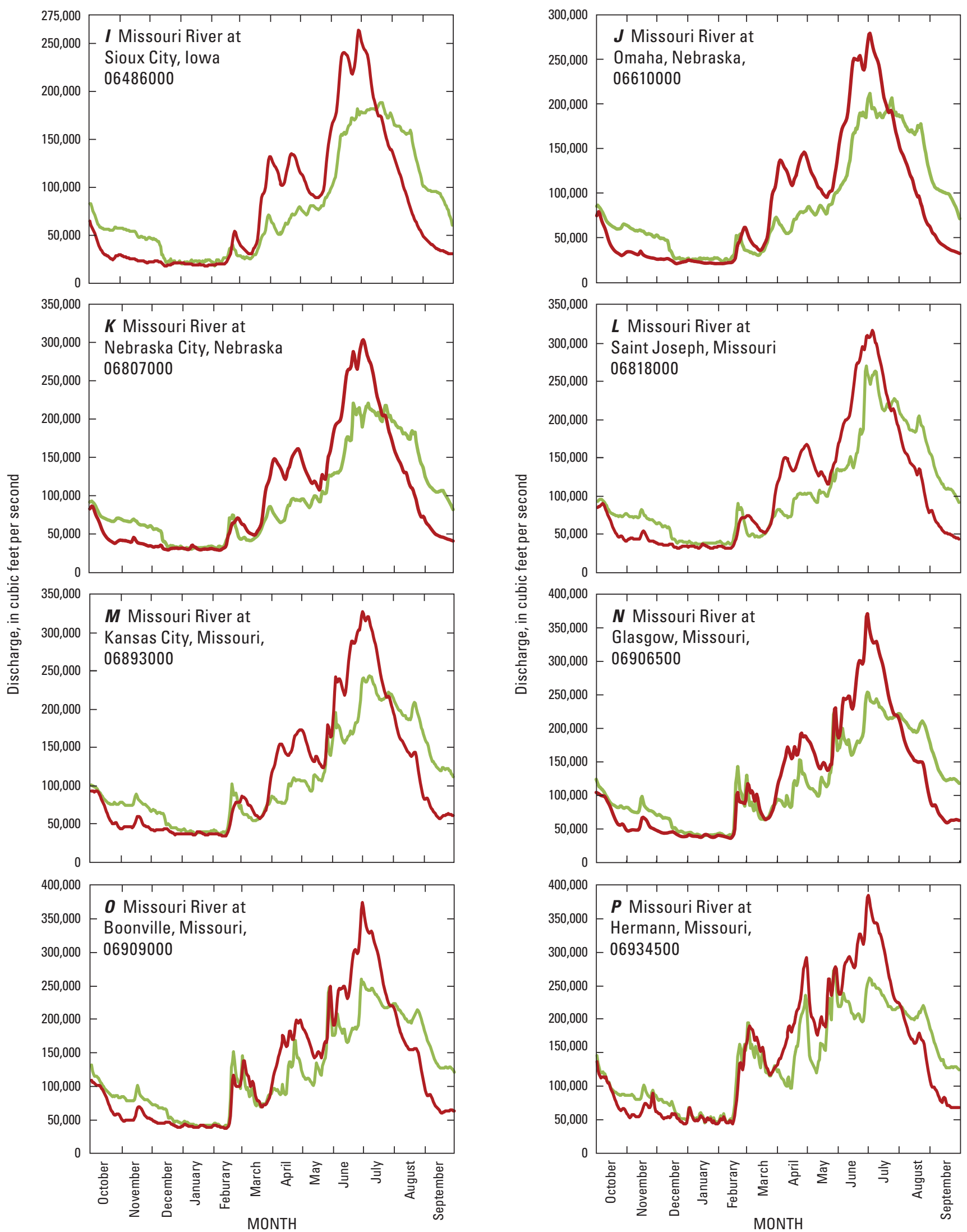

Figure 9. Unregulated daily mean streamflow simulated using the Missouri River Precipitation-Runoff Modeling System model as compared to measured regulated streamflows for selected locations on the Missouri River during 2011 water year.-

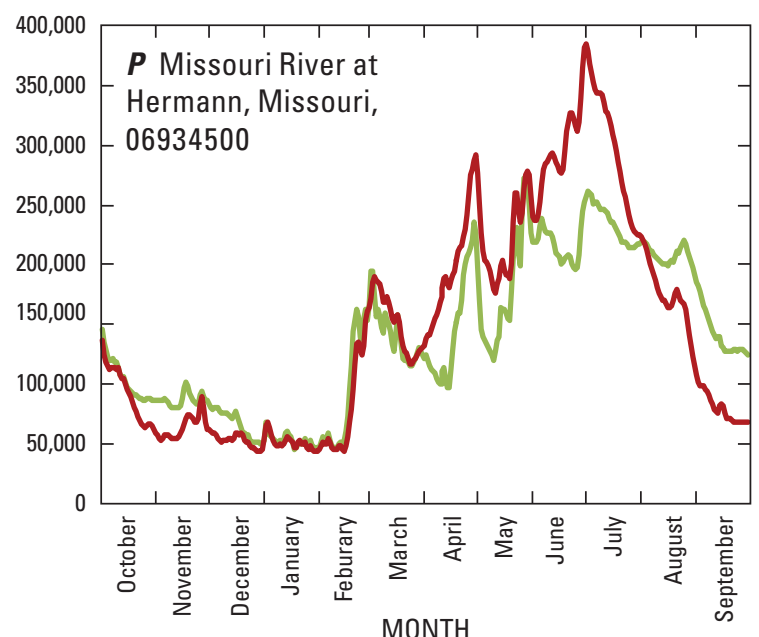
Continued 


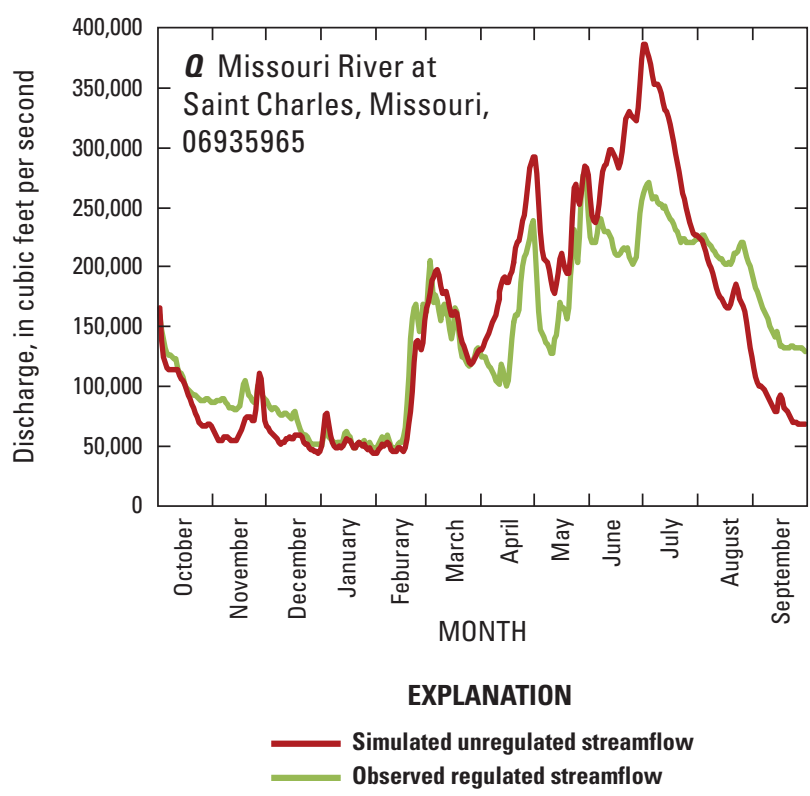

Figure 9. Unregulated daily mean streamflow simulated using the Precipitation-Runoff Modeling System (PRMS) model as compared to measured regulated streamflows for selected locations on the Missouri River during 2011 water year.-Continued

To further compare the effects of regulation on flood duration and severity, two additional methods of comparison are presented. The first method compares the number of days in which SDAD values were greater than or equal to the maximum MDAD value (table 4). This difference is the number of days streamflow would have exceeded the measured peak daily flow had no regulation been in place. The second method of comparison uses simulated flow, measured flow, measured stream stage record (elevation of the surface of the stream above NAVD 29 datum), and National Weather Service (NWS) 2011 flood category stage thresholds for Minor, Moderate, and Major Flood events (W. Ross, National Oceanic and Atmospheric Administration, written commun., 2013). This method establishes a metric, the unregulated difference in stage (UDS), which is calculated for each NWS flood category stage threshold (Minor, Moderate, and Major), and represents the number of additional days a stage threshold would have been exceeded if no regulation was in place. UDS is calculated:

$U D S_{\text {stage }}=\left(\right.$ no. of days $\left.Q_{s m}>Q_{\text {stage }}\right)-\left(\right.$ no. of days $\left.Q_{M}>Q_{\text {stage }}\right)$

where

$\begin{array}{cl}Q_{S I M} & \text { is simulated flow } \\ Q_{M} & \text { is measured flow } \\ Q_{\text {stage }} & \text { is the minimum stream flow associated with } \\ & \text { NWS flood stage threshold, and } \\ \text { no. } & \text { is number. }\end{array}$

Available USGS NWIS measured stage records at each streamgage were collected from USGS Water Science Centers for WY 2011 and used in the UDS calculation (U.S. Geological Survey, 2013). Simulated stage values were determined from simulated discharge values using 2011 stage-discharge ratings that were developed at each USGS streamgaging station (U.S. Geological Survey, 2013). For this, MDAD values associated with each NWS flood stage exceedance on both rising and falling limbs were established. When SDAD exceeded the MDAD associated with a NWS flood stage threshold, the Missouri River (simulation) was inferred to have exceeded the flood stage. The number of days each NWS flood stage would have been met or exceeded were counted in both the measured and simulated data, and compared using the UDS metric (table 4). If a particular NWS flood stage category threshold was not reached at a specific streamgage in the measured record, but was met or exceeded in the simulation, the USGS NWIS stage-discharge rating curve in effect for 2011 was used to estimate flow for stage exceedance.

\section{Fort Peck Dam and Culbertson, Montana}

The Missouri River model simulated flows for the streamgage location below Fort Peck Dam show that the dam eliminated an early summer peak flow with a SDAD value of $79,300 \mathrm{ft}^{3} / \mathrm{s}$ (fig. $9 A$ ). The dam also lowered a second summer peak flow with the maximum SDAD value of $92,000 \mathrm{ft}^{3} / \mathrm{s}$ to $65,900 \mathrm{ft}^{3} / \mathrm{s}$ (MDAD). Both maximum SDAD and MDAD values for 2011 are greater than the measured peak discharge values from 1952 (table 4). Simulated flows during August and September show the river receding to approximately $10,000 \mathrm{ft}^{3} / \mathrm{s}$, whereas, because of regulated releases from Fort Peck Dam, actual, measured flows remained at approximately $25,000 \mathrm{ft}^{3} / \mathrm{s}$ during those months. Model results show that without upstream regulation, SDAD values would have equaled or exceeded the maximum MDAD value for 23 days (table 4). NWS flood category stage thresholds are not established at this location; therefore UDS metrics were not calculated.

For the streamgage location near Culbertson, Montana, the downstream effects of regulation are similar to those at Fort Peck Dam. Here an early summer peak with a SDAD value of $102,400 \mathrm{ft}^{3} / \mathrm{s}$ was eliminated by upstream regulation, and a second summer peak with the maximum SDAD value of $117,900 \mathrm{ft}^{3} / \mathrm{s}$ was reduced to $97,200 \mathrm{ft}^{3} / \mathrm{s}$ (fig. 9B). Both maximum SDAD and MDAD values for 2011 are greater than the measured peak discharge values from 1952 (table 4). The model results show that during August and September, SDAD values would have been approximately $11,000 \mathrm{ft}^{3} / \mathrm{s}$. Instead, controlled releases from Fort Peck Dam maintained a base flow of approximately $25,000 \mathrm{ft}^{3} / \mathrm{s}$ during these months. Model results show that without upstream regulation, SDAD values would have met or exceeded the maximum MDAD value for 13 days (table 4). During 2011, MDAD and SDAD values did 
not exceed the NWS Minor Flood stage threshold, therefore UDS metrics were not calculated at this gage.

\section{Garrison Dam and Bismarck, North Dakota}

The Missouri River model simulated flows for the streamgage location at Garrison Dam show that upstream regulation eliminated an early summer peak flow, with the maximum SDAD value of 206,800 $\mathrm{ft}^{3} / \mathrm{s}$ (fig. 9C). Upstream regulation also lowered a second summer peak flow, with an SDAD value of $200,100 \mathrm{ft}^{3} / \mathrm{s}$ to $150,600 \mathrm{ft}^{3} / \mathrm{s}$ (MDAD). Both maximum SDAD and MDAD values for 2011 are less than the measured peak discharge values from 1952 (table 4).The model shows decreased SDAD values during August and September relative to MDAD values, which converge with MDAD values of approximately $25,000 \mathrm{ft}^{3} / \mathrm{s}$ by the end of the water year (September 30, 2011). Model results show that without upstream regulation, SDAD values would have met or exceeded the maximum MDAD value for 35 days (table 4). No NWS flood stage information was available at this location; therefore no UDS metrics could be calculated.

For the streamgage location at Bismarck, North Dakota, which is downstream of Garrison Dam, upstream regulation eliminated an early summer peak flow with the maximum SDAD value of $207,700 \mathrm{ft}^{3} / \mathrm{s}$ (table 4 and fig. 9D). Upstream regulation also lowered a second summer peak flow with an SDAD value of $199,300 \mathrm{ft}^{3} / \mathrm{s}$ to $154,000 \mathrm{ft}^{3} / \mathrm{s}$ (the maximum MDAD value). Both maximum SDAD and MDAD values for 2011 are less than the measured peak discharge values from 1952 (table 4). As at Garrison Dam, the model shows decreased SDAD values during August and September relative to MDAD values, which converge with MDAD values of approximately $25,000 \mathrm{ft}^{3} / \mathrm{s}$ by the end of the water year. Model results show that without upstream regulation, SDAD values would have met or exceeded the maximum MDAD value for 35 days (table 4 ).

During 2011, the NWS Major Flood stage was reached at Bismarck, North Dakota. The UDS for Major Flood stage is 4 days, however the UDS for Moderate Flood stage is -9 days and Minor Flood stage is -10 days. These results indicate that upstream regulation decreased the number of days at Major Flood stage and increased the number of days at Minor and Moderate Flood stages.

\section{Oahe Dam, South Dakota}

The Missouri River model simulated flows for the streamgage location at Oahe Dam show that upstream regulation eliminated an early summer peak flow with the maximum SDAD value of $220,900 \mathrm{ft}^{3} / \mathrm{s}$ (fig. $9 E$ ). Upstream regulation also lowered a second summer peak flow with an SDAD value of $212,800 \mathrm{ft}^{3} / \mathrm{s}$ to $160,300 \mathrm{ft}^{3} / \mathrm{s}$ (the maximum MDAD value). Both maximum SDAD and MDAD values for 2011 are less than the measured peak discharge values from 1952 (table 4).
The model shows decreased SDAD values during August and September relative to MDAD values, which begin to converge with MDAD values at the end of the water year. Model results show that without upstream regulation, SDAD values would have met or exceeded the maximum MDAD value for 36 days (table 4). No NWS flood stage information was available at this location; therefore no UDS metrics could be calculated.

\section{Big Bend Dam, South Dakota}

The Missouri River model simulated flows for the streamgage location at Big Bend Dam show that regulation eliminated an early summer peak flow with the maximum SDAD value of $220,400 \mathrm{ft}^{3} / \mathrm{s}$ (fig. $9 F$ ). Upstream regulation also lowered a second summer peak flow, with a SDAD value of $217,600 \mathrm{ft}^{3} / \mathrm{s}$ to $166,300 \mathrm{ft}^{3} / \mathrm{s}$ (the maximum MDAD value). Both maximum SDAD and MDAD values for 2011 are less than the measured peak discharge values from 1952 (table 4).The model shows decreased SDAD values during August and September relative to MDAD values, which begin to converge with MDAD values at the end of the water year. Model results show that without upstream regulation, SDAD values would have met or exceeded the maximum MDAD value for 35 days (table 4). No NWS flood stage information was available at this location; therefore no UDS metrics could be calculated.

\section{Fort Randall Dam, South Dakota}

The Missouri River model simulated flows for the streamgage location at Fort Randall Dam show that regulation eliminated an early summer peak flow with an SDAD value of $221,000 \mathrm{ft}^{3} / \mathrm{s}$ (fig. $9 G$ ). Upstream regulation also lowered a second summer peak flow with the maximum SDAD value of $236,700 \mathrm{ft}^{3} / \mathrm{s}$ to $160,000 \mathrm{ft}^{3} / \mathrm{s}$ (the maximum MDAD value). Both maximum SDAD and MDAD values for 2011 are less than the measured peak discharge values from 1952 (table 4). The model shows decreased SDAD values during August and September relative to MDAD values, which begin to converge with MDAD values at the end of the water year. Model results show that without upstream regulation, SDAD values would have met or exceeded the maximum MDAD value for 39 days (table 4). No NWS flood stage information was available at this location; therefore no UDS metrics could be calculated.

\section{Gavins Point Dam, South Dakota}

The Missouri River model simulated flows for the streamgage location at Gavins Point Dam show that regulation eliminated an early summer peak flow with an SDAD value of $223,300 \mathrm{ft}^{3} / \mathrm{s}$ (fig. $9 H$ ). Upstream regulation also lowered a second summer peak flow with the maximum SDAD value of $241,100 \mathrm{ft}^{3} / \mathrm{s}$ to $160,700 \mathrm{ft}^{3} / \mathrm{s}$ (the maximum MDAD value). 
Table 4. Maximum measured and maximum simulated daily average discharge and number of days that the National Weather Service (NWS) flood category stage threshold was exceeded for selected U.S. Geological Survey (USGS) streamgages and United States Army Corps of Engineers (USACE) dam outflow sites.

[USGS, U.S. Geological Survey; MDAD, Measured Daily Average Discharge; SDAD, Simulated Daily Average Discharge; ft3/s, cubic feet per second; NWS, National Weather Service; Stage, height of water surface above datum at which minor, moderate, or major flooding occurs; Meas, Measured data; Sim, Simulation data; UDS, Uregulated Difference in Stage (this number represents the increase or decrease in the number of days at or above NWS Flood Stage during the 2011 Flood if no regulation was present on the Missouri main stem); -, No floods stages determined at these sites; *, measured or simulated flows did not meet or exceed stage; na, not available]

\begin{tabular}{|c|c|c|c|c|c|c|c|c|c|c|c|c|c|c|}
\hline \multirow{3}{*}{$\begin{array}{c}\text { USGS } \\
\text { streamgage } \\
\text { number }\end{array}$} & \multirow{3}{*}{ USGS station name } & \multirow{3}{*}{$\begin{array}{c}2011 \\
\text { Maximum } \\
\text { MDAD } \\
\left(\mathrm{ft}^{3} / \mathbf{s}\right)\end{array}$} & \multirow{3}{*}{$\begin{array}{l}2011 \\
\text { Maximum } \\
\text { SDAD } \\
\left(\mathrm{ft}^{3} / \mathrm{s}\right)\end{array}$} & \multicolumn{9}{|c|}{ Number of days stage was at or above NWS flood stage threshold } & \multirow{3}{*}{$\begin{array}{c}\text { Number of } \\
\text { days maxi- } \\
\text { mum SDAD } \\
\text { exeeded } \\
\text { maximum } \\
\text { MDAD }\end{array}$} & \multirow{3}{*}{$\begin{array}{c}1952 \text { Mea- } \\
\text { sured peak } \\
\text { discharge, } \\
\left(\mathrm{ft}^{3} / \mathrm{s}\right), \\
(\mathrm{wells}, \\
1955)\end{array}$} \\
\hline & & & & \multicolumn{3}{|c|}{ Minor flood } & \multicolumn{3}{|c|}{ Moderate flood } & \multicolumn{3}{|c|}{ Major flood } & & \\
\hline & & & & Meas & Sim & UDS & Meas & Sim & UDS & Meas & Sim & UDS & & \\
\hline 06132000 & $\begin{array}{l}\text { Missouir River } \\
\text { below Fort Peck } \\
\text { Dam, Montana }\end{array}$ & 65,900 & 92,000 & - & - & - & - & - & - & - & - & - & 23 & 27,400 \\
\hline 06185500 & $\begin{array}{l}\text { Missouri River } \\
\text { near Culbertson, } \\
\text { Montana }\end{array}$ & 97,200 & 117,900 & $*$ & * & $*$ & $*$ & $*$ & $*$ & $*$ & $*$ & $*$ & 13 & 46,800 \\
\hline 06338490 & $\begin{array}{c}\text { Missouri River at } \\
\text { Garrison Dam, } \\
\text { North Dakota }\end{array}$ & ${ }^{1} 150,600$ & 206,800 & - & - & - & - & - & - & - & - & - & 35 & ${ }^{7} 348,000$ \\
\hline 06342500 & $\begin{array}{l}\text { Missouri River at } \\
\text { Bismarck, North } \\
\text { Dakota }\end{array}$ & 154,000 & 207,700 & 99 & 89 & -10 & 77 & 68 & -9 & 49 & 53 & 4 & 35 & 500,000 \\
\hline 509990006 & $\begin{array}{l}\text { Missouri River at } \\
\text { Oahe Dam, South } \\
\text { Dakota }\end{array}$ & ${ }^{2} 160,300$ & 220,900 & - & - & - & - & - & - & - & - & - & 36 & ${ }^{8} 440,000$ \\
\hline 509990007 & $\begin{array}{l}\text { Missouri River at } \\
\text { Big Bend Dam, } \\
\text { South Dakota }\end{array}$ & ${ }^{3} 166,300$ & 220,400 & - & - & - & - & - & - & - & - & - & 35 & ${ }^{9} 440,000$ \\
\hline 06453000 & $\begin{array}{l}\text { Missouri River } \\
\text { at Fort Randall } \\
\text { Dam, South } \\
\text { Dakota }\end{array}$ & 160,000 & 236,700 & - & - & - & - & - & - & - & - & - & 39 & 447,000 \\
\hline 509990008 & $\begin{array}{l}\text { Missouri River at } \\
\text { Gavins Point } \\
\text { Dam, South } \\
\text { Dakota }\end{array}$ & ${ }^{4} 160,700$ & 241,100 & - & - & - & - & - & - & - & - & - & 40 & ${ }^{10} 480,000$ \\
\hline 06486000 & $\begin{array}{l}\text { Missouri River at } \\
\text { Sioux City, Iowa }\end{array}$ & 189,000 & 264,500 & 81 & 84 & 3 & 66 & 56 & -10 & $*$ & 635 & 35 & 37 & 441,000 \\
\hline 06610000 & $\begin{array}{l}\text { Missouri River at } \\
\text { Omaha, Nebraska }\end{array}$ & 212,000 & 279,500 & 101 & 131 & 30 & 75 & 66 & -9 & $*$ & $*$ & $*$ & 34 & 396,000 \\
\hline
\end{tabular}


Table 4. Maximum measured and maximum simulated daily average discharge and number of days that the National Weather Service (NWS) flood category stage threshold was exceeded for selected U.S. Geological Survey (USGS) streamgages and United States Army Corps of Engineers (USACE) dam outflow sites.-Continued

[USGS, U.S. Geological Survey; MDAD, Measured Daily Average Discharge; SDAD, Simulated Daily Average Discharge; ft3/s, cubic feet per second; NWS, National Weather Service; Stage, height of water surface above datum at which minor, moderate, or major flooding occurs; Meas, Measured data; Sim, Simulation data; UDS, Uregulated Difference in Stage (this number represents the increase or decrease in the number of days at or above NWS Flood Stage during the 2011 Flood if no regulation was present on the Missouri main stem); -, No floods stages determined at these sites; *, measured or simulated flows did not meet or exceed stage; na, not available]

\begin{tabular}{|c|c|c|c|c|c|c|c|c|c|c|c|c|c|c|}
\hline \multirow{3}{*}{$\begin{array}{c}\text { USGS } \\
\text { streamgage } \\
\text { number }\end{array}$} & \multirow{3}{*}{ USGS station name } & \multirow{3}{*}{$\begin{array}{c}2011 \\
\text { Maximum } \\
\text { MDAD } \\
\left(\mathrm{ft}^{3} / \mathrm{s}\right)\end{array}$} & \multirow{3}{*}{$\begin{array}{l}2011 \\
\text { Maximum } \\
\text { SDAD } \\
\left(\mathrm{ft}^{3} / \mathrm{s}\right)\end{array}$} & \multicolumn{9}{|c|}{ Number of days stage was at or above NWS flood stage threshold } & \multirow{3}{*}{$\begin{array}{c}\text { Number of } \\
\text { days maxi- } \\
\text { mum SDAD } \\
\text { exeeded } \\
\text { maximum } \\
\text { MDAD }\end{array}$} & \multirow{3}{*}{$\begin{array}{c}1952 \text { Mea- } \\
\text { sured peal } \\
\text { discharge } \\
\left(\mathrm{ft}^{3} / \mathrm{s}\right), \\
\text { (wells, } \\
1955)\end{array}$} \\
\hline & & & & \multicolumn{3}{|c|}{ Minor flood } & \multicolumn{3}{|c|}{ Moderate flood } & \multicolumn{3}{|c|}{ Major flood } & & \\
\hline & & & & Meas & Sim & UDS & Meas & Sim & UDS & Meas & Sim & UDS & & \\
\hline 06807000 & $\begin{array}{l}\text { Missouri River at } \\
\text { Nebraska City, } \\
\text { Nebraska }\end{array}$ & 221,000 & 303,800 & 169 & 154 & -15 & 65 & 93 & 28 & 10 & 53 & 43 & 45 & 414,000 \\
\hline 06818000 & $\begin{array}{l}\text { Missouri River at } \\
\text { Saint Joseph, } \\
\text { Missouri }\end{array}$ & 270,000 & 317,000 & 160 & 152 & -8 & 104 & 91 & -13 & 46 & 51 & 5 & 26 & 397,000 \\
\hline 06893000 & $\begin{array}{c}\text { Missouri River at } \\
\text { Kansas City }\end{array}$ & 243,000 & 327,700 & 8 & 41 & 33 & $*$ & 626 & 26 & $*$ & $*$ & $*$ & 34 & 400,000 \\
\hline 06906500 & $\begin{array}{l}\text { Missouri River at } \\
\text { Glasgow, Mis- } \\
\text { souri }\end{array}$ & 254,000 & 374,200 & 95 & 92 & -3 & 70 & 67 & -3 & $*$ & 628 & 28 & 33 & na \\
\hline 06909000 & $\begin{array}{l}\text { Missouri River at } \\
\text { Boonville, Mis- } \\
\text { souri }\end{array}$ & 260,000 & 374,200 & 102 & 103 & 1 & $*$ & * & * & $*$ & $*$ & $*$ & 32 & 360,000 \\
\hline 06934500 & $\begin{array}{l}\text { Missouri River at } \\
\text { Hermann, Mis- } \\
\text { souri }\end{array}$ & 274,000 & 385,200 & 107 & 100 & -7 & 3 & 53 & 50 & $*$ & $*$ & * & 52 & 368,000 \\
\hline 06935965 & $\begin{array}{l}\text { Missouri River at } \\
\text { Saint Charles, } \\
\text { Missouri }\end{array}$ & 277,000 & 387,100 & 71 & 90 & 19 & $*$ & 628 & 28 & $*$ & $*$ & $*$ & 51 & na \\
\hline
\end{tabular}

${ }^{1}$ Peak reservoir outflow same as USGS streamgage 06339000, Missouri River below Garrison Dam, North Dakota.

${ }^{2}$ Peak reservoir outflow same as USGS streamgage 06440000, Missouri River at Pierre, South Dakota.

${ }^{3}$ Peak reservoir outflow same as USGS streamgage 06443000, Missouri River at Chamberlain, South Dakota.

${ }^{4}$ Peak reservoir outflow same as USGS streamgage 06467500, Missouri River at Yankton, South Dakota.

${ }^{5}$ U.S. Army Corps of Engineers reservoir outflow sites.

${ }^{6}$ Stage not met in 2011 water year: stage-discharge relation inferred from 2011 rating curve (U.S. Geological Survey, 2013).

${ }^{7}$ Discharge values from 06339000 Missouri River below Garrison Dam, North Dakota.

${ }^{8}$ Discharge values from 06440000 Missouri River at Pierre, South Dakota.

${ }^{9}$ Discharge values from 06443000 Missouri River at Chamberlain, South Dakota.

${ }^{10}$ Discharge values from 0647500 Missouri River at Yankton, South Dakota. 
Both maximum SDAD and MDAD values for 2011 are less than the measured peak discharge values from 1952 (table 4). The model shows decreased SDAD values during August and September relative to MDAD values, which begin to converge with MDAD values at the end of the water year. Model results show that without upstream regulation, SDAD values would have met or exceeded the maximum MDAD value for 40 days (table 4). No NWS flood stage information was available at this location; therefore no UDS metrics could be calculated.

\section{Sioux City, lowa}

At the Sioux City, Iowa streamgage location, the model simulated two spring peak flows with SDAD values of 132,300 and $134,800 \mathrm{ft}^{3} / \mathrm{s}$, and two summer peak flows with SDAD values of 240,500 and $264,500 \mathrm{ft}^{3} / \mathrm{s}$ (fig. 9I). Upstream regulation eliminated the spring peak flows and consolidated the summer peak flows into one long, high-flow event with a maximum MDAD value of $189,000 \mathrm{ft}^{3} / \mathrm{s}$. Both maximum SDAD and MDAD values for 2011 are less than the measured peak discharge values from 1952 (table 4). The model shows decreased SDAD values during August and September relative to MDAD values, which begin to converge with MDAD values at the end of the water year. Model results show that without upstream regulation, SDAD values would have met or exceeded the maximum MDAD value for 37 days (table 4).

During 2011, the NWS Moderate and Minor Flood stages were reached at this streamgage. Model results show that, without upstream regulation, Major Flood stage also would have been reached. The UDS for Major Flood Stage is 35 days; the UDS for Moderate Flood stage is -10 days; the UDS for Minor Flood stage is 3 days. These metrics indicate that upstream regulation decreased the number of days at Major and Moderate Flood stages and increased the number of days at Minor Flood stage.

\section{Omaha, Nebraska}

At the Omaha, Nebraska streamgage location, the model simulated two spring peak flows with SDAD values of 137,300 and $145,200 \mathrm{ft}^{3} / \mathrm{s}$, and two summer peak flows with SDAD values of 254,500 and $279,500 \mathrm{ft}^{3} / \mathrm{s}$ (fig. 9J). Upstream regulation eliminated the spring peak flows and lowered the summer peak flows to 190,000 and $212,000 \mathrm{ft}^{3} / \mathrm{s}$ (MDAD values), respectively. Both maximum SDAD and MDAD values for 2011 are less than the measured peak discharge values from 1952 (table 4). The model shows decreased SDAD values during August and September relative to MDAD values, which begin to converge with MDAD values at the end of the water year. Model results show that without upstream regulation, SDAD values would have met or exceeded the maximum MDAD value for 34 days (table 4).

During 2011, the NWS Moderate and Minor Flood stages were exceed at this streamgage in both the measured and simulated flow records. The UDS for Moderate Flood stage is -9 days and the UDS for Minor Flood stage is 30 days. These metrics indicate that upstream regulation increased the number of days at Moderate Flood stage and largely decreased the number of days at Minor Flood stage, but do not indicate that regulation increased the severity of the flooding. Although Major Flood stage was not met at Omaha, Nebraska, simulated flows did exceed the maximum measured flow for 34 days. The decrease in the maximum peak flow by regulation is the cause for the increase in the number of days at or above Moderate Flood stage.

\section{Nebraska City, Nebraska}

At Nebraska City, Nebraska, the model simulated two spring peak flows with SDAD values of 148,500 and $161,500 \mathrm{ft}^{3} / \mathrm{s}$, and two summer peak flows with SDAD values of 288,300 and $303,800 \mathrm{ft}^{3} / \mathrm{s}$ (fig. $9 K$ ). Upstream regulation eliminated the spring peak flows and lowered the summer peak flows to $221,000 \mathrm{ft}^{3} / \mathrm{s}$ (maximum MDAD value). Both maximum SDAD and MDAD values for 2011 are less than the measured peak discharge values from 1952 (table 4). The model shows decreased SDAD values during August and September relative to MDAD values, which begin to converge with MDAD values at the end of the water year. Model results show that without upstream regulation, SDAD values would have met or exceeded the maximum MDAD value for 45 days (table 4).

During 2011, the NWS Major Flood stage was exceeded at this streamgage in both the measured and simulated flow records. The UDS for Major Flood stage is 43 days and the UDS for Moderate and Minor Flood stages are 28 and -15 days. These metrics indicate that upstream regulation decreased the number of days at Major Flood and Moderate Flood stages and increased the number of days at Minor Flood stage (table 4).

\section{Saint Joseph, Missouri}

At the Saint Joseph, Missouri streamgage location, the model simulated two spring peak flows with SDAD values of 150,100 and $167,200 \mathrm{ft}^{3} / \mathrm{s}$, and one summer peak flow with the maximum SDAD value of $317,000 \mathrm{ft}^{3} / \mathrm{s}$ (fig. $9 L$ ). Upstream regulation reduced the spring peak flows in number and magnitude to a single spring flood peak with a maximum MDAD value of $104,000 \mathrm{ft}^{3} / \mathrm{s}$, and reduced the summer peak flow to a maximum MDAD value of $270,000 \mathrm{ft}^{3} / \mathrm{s}$. Both maximum SDAD and MDAD values for 2011 are less than the measured peak discharge values from 1952 (table 4). The model shows decreased SDAD values during August and September relative to MDAD values, which begin to converge with MDAD values at the end of the water year. Model results show that without upstream regulation, SDAD values would have met or exceeded the maximum MDAD value for 26 days (table 4). 
During 2011, the NWS Major Flood stage was exceeded at this streamgage in both the measured and simulated flow records. The UDS for Major Flood stage is 5 days and the UDS for Moderate and Minor Flood stages are -13 and -8 days. These metrics indicate that upstream regulation decreased the number of days at Major Flood stage and increased the number of days at Moderate Flood and Minor Flood stages (table 4).

\section{Kansas City, Missouri}

The Missouri River model simulated flows at the Kansas City, Missouri streamgage location show that upstream regulation lowered a spring peak flow with an SDAD value of $173,000 \mathrm{ft}^{3} / \mathrm{s}$ to $117,000 \mathrm{ft}^{3} / \mathrm{s}$ (MDAD value), and lowered a summer peak flow with the maximum SDAD value of $327,700 \mathrm{ft}^{3} / \mathrm{s}$ to $243,000 \mathrm{ft}^{3} / \mathrm{s}$ (maximum MDAD value) (fig. 9M). Both maximum SDAD and MDAD values for 2011 are less than the measured peak discharge values from 1952 (table 4). The model shows decreased SDAD values during August and September relative to MDAD values, which begin to converge with MDAD values at the end of the water year. Model results show that without upstream regulation, SDAD values would have met or exceeded the maximum MDAD value for 34 days (table 4 ).

During 2011, the NWS Minor Flood stage was exceeded at this streamgage in the measured and simulated flow records and Moderate Flood stage was exceeded in the simulated flow records. The UDS for Moderate Flood stage is 26 days, and the UDS for Minor Flood stage is 33 days. These metrics indicate that upstream regulation decreased the number of days at Moderate Flood and Minor flood stages (table 4). The simulation indicates that Major Flood stage would have not been reached.

\section{Glasgow, Missouri}

The Missouri River model simulated flows at the Glasgow, Missouri streamgage show that upstream regulation lowered a spring peak flow with an SDAD value of 199,200 $\mathrm{ft}^{3} / \mathrm{s}$ to $153,000 \mathrm{ft}^{3} / \mathrm{s}$ (MDAD value), and lowered a summer peak flow with the maximum SDAD value of $374,200 \mathrm{ft}^{3} / \mathrm{s}$ to $254,000 \mathrm{ft}^{3} / \mathrm{s}$ (maximum MDAD value) (fig. $9 \mathrm{~N}$ ). No measured peak discharge value was available for 1952 (table 4). The model shows decreased SDAD values during August and September relative to MDAD values, which begin to converge with MDAD values at the end of the water year. Model results show that without upstream regulation, SDAD values would have met or exceeded the maximum MDAD value for 33 days (table 4).

During 2011, the NWS Moderate Flood stage was exceeded at this streamgage in the measured and simulated records and NWS Major Flood stage was exceeded in the simulated flow records. The UDS for Major Flood stage is
28 days and the UDS for Moderate and Minor Flood stages are both -3 days. These metrics indicate that upstream regulation decreased the number of days at Major Flood stage and increased the number of days at Moderate Flood and Minor Flood stages (table 4).

\section{Boonville, Missouri}

The Missouri River model simulated flows at the Boonville, Missouri streamgage location show that upstream regulation lowered a spring peak flow with an SDAD value of $199,300 \mathrm{ft}^{3} / \mathrm{s}$ to $168,000 \mathrm{ft}^{3} / \mathrm{s}$ (MDAD value), and lowered a summer peak flow with the maximum SDAD value of $374,200 \mathrm{ft}^{3} / \mathrm{s}$ to $260,000 \mathrm{ft}^{3} / \mathrm{s}$ (maximum MDAD value) (fig. $9 M$ ). The maximum MDAD value for 2011 is less than the measured peak discharge values from 1952, however the maximum SDAD value for 2011 is greater than the measured peak discharge value from 1952 (table 4). The model shows decreased SDAD values during August and September relative to MDAD values, which begin to converge with MDAD values at the end of the water year. Model results show that without upstream regulation, SDAD values would have met or exceeded the maximum MDAD value for 32 days (table 4).

During 2011, the NWS Minor Flood stage was exceeded at this streamgage in the measured and simulated flow records. The UDS for Minor Flood stage is 1 day. The simulation indicates that Major and Moderate Flood stage would have not been reached in the absence of regulation. Note the small UDS value is due to the elimination of spring flood period at this streamgage because of regulation. Although the summer flood period was extended because of regulation, the total measured number of days in flood is roughly equal to the sum of the simulated spring flood and summer flood periods (fig. 9O).

\section{Hermann, Missouri}

The Missouri River model simulated flows at the Hermann, Missouri streamgage location show that upstream regulation lowered a spring peak flow with an SDAD value of $292,700 \mathrm{ft}^{3} / \mathrm{s}$ to $235,000 \mathrm{ft}^{3} / \mathrm{s}$ (MDAD value), and lowered a summer peak flow with the maximum SDAD value of $385,200 \mathrm{ft}^{3} / \mathrm{s}$ to $261,000 \mathrm{ft}^{3} / \mathrm{s}$ (MDAD value) (fig. 9P). Note this summer MDAD peak flow is not the maximum MDAD value of $274,000 \mathrm{ft}^{3} / \mathrm{s}$, which occurred in May. The maximum MDAD value for 2011 is less than the measured peak discharge value from 1952, however the maximum SDAD value for 2011 is greater than the measured peak discharge value from 1952 (table 4). The model shows decreased SDAD values during August and September relative to MDAD values, which begin to converge with MDAD values at the end of the water year. Model results show that without upstream regulation, SDAD values would have met or exceeded the maximum MDAD value for 52 days (table 4). 
During 2011, the NWS Moderate Flood stage was exceeded at this streamgage in the measured and simulated flow records. The UDS for Moderate Flood stage is 50 days, and the UDS for Minor Flood stages is -7 days. These metrics indicate that upstream regulation decreased the number of days at Moderate Flood stage and increased the number of days at Minor Flood stage (table 4).

\section{Saint Charles, Missouri}

The Missouri River model simulated flows at the Saint Charles, Missouri streamgage location show that upstream regulation lowered a spring peak flow with an SDAD value of $292,400 \mathrm{ft}^{3} / \mathrm{s}$ to $239,000 \mathrm{ft}^{3} / \mathrm{s}$ (MDAD), and lowered a summer peak flow with the maximum SDAD value of $387,100 \mathrm{ft}^{3} / \mathrm{s}$ to $271,000 \mathrm{ft}^{3} / \mathrm{s}$ (MDAD value) (fig. 9Q). Note this summer peak flow is not the maximum MDAD value of $277,000 \mathrm{ft}^{3} / \mathrm{s}$, which occurred earlier in May. Measured peak discharge was not available for 1952 (table 4). The model shows decreased SDAD values during August and September relative to MDAD values, which begin to converge with MDAD values at the end of the water year. Model results show that without upstream regulation, SDAD values would have met or exceeded the maximum MDAD value for 51 days (table 4).

During 2011, the NWS Minor Flood stage was exceeded at this streamgage in the measured and simulated records and Moderate Flood stage was exceeded in the simulated flow records. The UDS for Minor Flood stage is 19 days and the UDS for Moderate Flood stage is 28 days. At Saint Charles, Missouri, regulation reduced number of days at or exceeding Minor Flood stage and eliminated all days when the river would have met or exceeded Moderate Flood stage.

\section{Model Limitations}

There are several notable limitations in the Missouri River model. First, the model simulates a daily time step, with all flows and storages expressed as daily mean values. Because of this, error may result because of the daily averaging of flows, or when streamflow changes at subdaily time increments (Markstrom and others, 2012). Second, the HRU sizes are large, and parameter values, flows, and storages are assumed to be homogeneous within each HRU. Because of the coarse spatial resolution of the model, some hydrologic complexity and parameter variability within an HRU are lost. Third, the method of simulating solar radiation values for each HRU does not account for variations in solar activity or changes in weather events. This limitation, however, typically results in only small changes in solar radiation, which have a minimal effect on hydrologic variables and projected basin runoff (Markstrom and others, 2012). Fourth, complications occur in simulations when rain falls on the snowpack in excess of its available pore space; either the water will runoff the snowpack, in which case it is erroneously simulated as snowmelt, or the water will freeze to the snowpack, causing the model to later report more snowmelt than snowfall (Markstrom and others, 2012). Both of these cases may complicate interpretation of the model results with regard to rain on snowpack events. Fifth, this study used the Jensen-Haise method (Jensen and others 1970; and Markstrom and others, 2008) to estimate stationary monthly mean values for potential evapotranspiration (PET) at each calibration point for subbasin model calibration, which may be a source of uncertainty in the model. Studies (Kingston and others, 2009; Donohue and others, 2010) report that this uncertainty is reduced because PRMS uses simulated PET, vegetation type, land-use characteristics, soil type, simulated atmospheric conditions, and soil moisture availability to compute actual evapotranspiration (AET), and it is AET that PRMS used in the water balance simulation (Markstrom and others, 2008; and Markstrom and others, 2012). A more detailed discussion of PET uncertainty in the PRMS model is presented in Markstrom and others (2012).

The Missouri River model was designed and calibrated to simulate the peak flows in the Missouri River for the 2011 water year. Because of this, the model has further assumptions and limitations that bear mentioning. First, the model was built using streamgage data from tributary streams as inflows to better simulate the effects of Missouri River regulation on flows. Because of this, the model does not simulate tributary stream flows. Second, several tributary inflow and calibration streamgages on the Missouri River have limited measurement records, which reduced the model calibration and simulation periods in certain reaches, making it impossible in the current model configuration to simulate flows for all years. Third, precise calibration of the Missouri River subbasin models upstream from Gavins Point Dam was problematic because available streamgage data on the reaches affected by storage and controlled releases represent regulated flow conditions, and are therefore not appropriate for model calibration. In these cases, USACE naturalized flows were used for model calibration at subbasin outlets, which may create more uncertainty in simulated flows upstream of Gavins Point Dam. This is evident in the statistical test results (PBIAS, PSP, NSE, and $R^{2}$ ) for the Missouri River at Bismarck, North Dakota (table 3). Fourth, the PRMS model assumes that all runoff flows to the channel and is routed to downstream segments. The model cannot simulate the effects of overbank storage from events such as natural flooding and levee failures. This may result in over-simulation of flood peaks during extreme flood events. Fifth, the model was calibrated with emphasis placed on the peak flow timing during high-flow months (April-August). As part of this approach and use of the Muskingum routing method, routing segment travel times, $k$, were decreased to improve peak timing. As a result, simulated flow peak timing during low-flow months may be less accurate. Sixth, water withdrawals or wastewater discharges were not 
addressed in the model. The effects were assumed to not be significant compared to runoff volumes of WY 2011.

The comparison of simulation results and measured flows at streamgages indicate that U.S. Army Corps of Engineers operation of the Reservoir System eliminated or greatly reduced spring peak flow events, consolidated two summer peak flow events to one with a markedly decreased magnitude, and maintained higher than normal base flow beyond the end of the water year. Additional comparative metrics using National Weather Service flood stages show that without the Reservoir System, flows greater than those measured would have been sustained for much longer, commonly in excess of 30 days, and overall the flooding associated with high-flow events would have been more severe, often progressing to a higher NWS flood stage threshold.

\section{Summary}

The Missouri River flows through the largest reservoir system in North America. The Missouri River Mainstem Reservoir System (Reservoir System), authorized by the 1944 Flood Control Act, consists of six dams (and reservoirs) constructed on the Missouri River-Fort Peck Dam (Fort Peck Lake), Garrison Dam (Lake Sakakawea), Oahe Dam (Lake Oahe), Big Bend Dam (Lake Sharpe), Fort Randall Dam (Lake Francis Case), and Gavins Point Dam (Lewis and Clark Lake). The Northwestern Division of the U.S. Army Corps of Engineers (USACE) operates the Reservoir System to manage Missouri River flows (regulation) for congressionally authorized purposes of flood control, irrigation, navigation, hydroelectric power generation, water supply, water quality, recreation, and fish and wildlife enhancement. The flooding and resulting damage during 2011 brought increased public attention to the U.S. Army Corps of Engineers (USACE) operation of the Reservoir System.

In order to provide a better understanding of the effects of regulation on the magnitude and duration of Missouri River flooding in 2011, the U.S. Geological Survey (USGS) Precipitation-Runoff Modeling System (PRMS) was used to construct and calibrate a watershed model to simulate unregulated flows, or flows that exclude the effects of Reservoir System operations, during the 2011 water year. Model results were compared with measured regulated flows during the same period to quantify the effects of regulation on stream flow and flooding at selected locations along the Missouri River. Simulated unregulated peak discharges for 2011 also are compared with historical peak discharges for the 1952 flood.

The Missouri River PRMS model was built at a coarseresolution using the Geospatial Fabric (GF), a new set of methods used by the USGS National Research Program (NRP) to aggregate the catchments and flow lines defined in the National Hydrography Dataset Plus dataset (NHDPlus) to align with the National Hydrologic Model specifications.
Daily Surface Weather and Climatological Summaries (DAYMET) were acquired for October 1, 1999 to September 30, 2011, and post-processed by the USGS Center for Integrated Data Analytics (CIDA) to provide 12 years of input data at a 1-kilometer grid for the Missouri River model construction and calibration. DAYMET data were spatially averaged for each HRU and downloaded using the USGS geodata portal. USGS streamgage data were collected using the USGS Downsizer program which accessed the USGS National Water Information System (USGS NWIS) and retrieved daily streamflow measurements at 100 sites for October 1, 1999, to September 30, 2011. Daily reservoir release data also were included in the model for all Reservoir System dams for that period.

The Missouri River PRMS model calibration was restricted to October 1, 2001 to September 30, 2011, to optimize model simulation of 2011 flows with emphasis placed on the peak flow timing and volumes during high-flow months (April-August). The percent bias (PBIAS), root mean square error-observation standard deviation ratio $(R S R)$, Nash Sutcliffe efficiency (NSE), and coefficient of determination $\left(R^{2}\right)$ statistics were used to evaluate model performance. Statistical tests indicate that the model is a good fit for most high-flow months and for annual streamflow estimation at all locations, with increased error associated with low-flow months and during high-flow events that involve overbank storage.

Simulated daily average discharge (SDAD) and measured daily average discharge (MDAD) values, maximum SDAD and MDAD values, and spring and summer SDAD and MDAD peak flow values, are compared directly (magnitude comparison). Two additional methods of comparison are presented to further compare the effects of regulation on flood duration and severity: the number of days in which SDAD values were greater than or equal to the maximum MDAD value, and the number of additional days a National Weather Service (NWS) Minor, Moderate, and Major Flood stage thresholds would have been exceeded if no regulation was in place.

The comparison of simulated unregulated flows to measured flows at dam and selected streamgage locations on the Missouri River (Fort Peck Dam, Montana; Culbertson, Montana; Garrison Dam, North Dakota; Bismarck, North Dakota; Oahe Dam, South Dakota; Big Bend Dam, South Dakota; Fort Randall Dam, South Dakota; Gavins Point Dam, South Dakota; Sioux City, Iowa; Omaha, Nebraska; Nebraska City, Nebraska; Saint Joseph, Missouri; Boonville, Missouri; Kansas City, Missouri; Glasgow, Missouri; Boonville, Missouri; and Saint Charles, Missouri) indicate that operation of the Reservoir System eliminated or greatly reduced spring peak flow events, consolidated two summer peak flow events to one with a markedly decreased magnitude, and maintained higher than normal base flow beyond the end of the water year. The simulated 2011 flood peaks were lower in magnitude than those measured during the 1952 flood, with the exception of Fort Peck and Culbertson, Montana, where the 2011 flood peaks were greater in magnitude. Additional comparative 
metrics using NWS flood stages show that without operation of the Reservoir System, flows greater than those measured would have been sustained for much longer, commonly in excess of 30 days, and overall the flooding associated with high-flow events would have been more severe, often progressing to a higher NWS flood stage threshold.

\section{References Cited}

Blodgett, D.L., 2013, The U.S. Geological Survey climate geo data portal - An integrated broker for climate and geospatial data: U.S. Geological Survey Fact Sheet 2013-3019, 2 p., accessed August 19, 2014, at http://pubs.usgs.gov/ $f_{S} / 2013 / 3019$

Brown, Juliane, B., Sprague, Lori, A., and Dupree, Jean, A., 2011, Nutrient sources and transport in the Missouri River Basin, with emphasis on the effects of irrigation and Reservoirs: Journal of the American Water Resources Association (JAWRA), v. 47, no. 5, p. 1034-1060, accessed August 19, 2014, at http://dx.doi.org/10.1111/j.1752-1688.2011.00584.x

Donohue, R.J., McVicar, T.R., and Roderick, M.L., 2010, Assessing the ability of potential evaporation formulations to capture the dynamics in evaporative demand within a changing climate: Journal of Hydrology, v. 386, p. 186-197.

Falcone, J., 2011, GAGES-II-Geospatial attributes of gages for evaluating streamflow: accessed March 2012 at $h t t p: / /$ water.usgs.gov/lookup/getspatial?gagesII_Sept2011.

Gassman, P.W., Reyes, M.R., Green, C.H., and Arnold, J.G., 2007, The soil and water assessment tool-Historical development, applications, and future research directions: Transactions of the American Society of Agricultural and Biological Engineers (ASABE), v. 50, no. 4, p. 1211-1250.

Gleeson, T., Smith, L., Moosdorf, N., Hartmann, J., Dürr, H.H., Manning, A.H., van Beek, L.P.H., and Jellinek, A.M., 2011, Mapping permeability over the surface of the Earth: Geophysical Research Letters, v. 38, no. L02401, 6 p., accessed August 19, 2014, at http://onlinelibrary.wiley.com/ doi/10.1029/2010GL045565/pdf.

Goode, D.J., Koerkle, E.H., Hoffman, S.A., Regan, R.S., Hay, L.E., and Markstrom, S.L., 2010, Simulation of runoff and reservoir inflow for use in a flood-analysis model for the Delaware River, Pennsylvania, New Jersey, and New York, 2004-2006: U.S. Geological Survey Open-File Report 2010-1014, 68 p., accessed August 19, 2014, at http://pubs. usgs.gov/of/2010/1014/.
Grigg, Neil, McCarthy, Cara, Lawrence, Bill, and Ockerman, Darwin, 2011, Review of the regulation of the Missouri River mainstem reservoir system during the flood of 2011: U.S. Army Corps of Engineers, Missouri River Basin Water Management Division, 93 p., accessed August 19, 2014, at http://www.nwd-mr.usace.army.mil/rcc/reports/pdfs/ MRIndependentReviewPanel.pdf.

Gupta, H.V., Sorooshian, S., and Yapo, P.O., 1999, Status of automatic calibration for hydrologic models - Comparison with multilevel expert calibration: Journal of Hydrologic Engineering, v. 4, no. 2, p.135-143.

Hay, L.E., and Umemoto, M., 2006, Multiple-objective stepwise calibration using Luca: U.S. Geological Survey OpenFile Report 2006-1323, 25 p., accessed August 19, 2014, at http://pubs.usgs.gov/of/2006/1323/pdf/OF06-1323_508.pdf.

Homer, C., Dewitz, J., Fry, J., Coan, M., Hossain, N., Larson, C., Herold, N., McKerrow, A., VanDriel, J.N., and Wickham, J., 2007, Completion of the 2001 National Land Cover Database for the conterminous United States: Photogrammetric Engineering and Remote Sensing, v. 73, no. 4, p. 337-341.

Horizon Systems Corporation, 2006, National Hydrography Dataset Plus (NHDPlus): Horizon Systems Corporation, accessed March 16, 2012, accessed August 19, 2014, at http://www.horizon-systems.com/nhdplus/.

Jensen, M.E., Robb, D.C.N., and Franzoy, C.E., 1970, Scheduling irrigations using climate-crop-soil data: Journal of Irrigation and Drainage Engineering, v. 96, p. 25-28.

Kalin, L., and Hantush, M.M., 2006, Hydrologic modeling of an Eastern Pennsylvania watershed with NEXRAD and rain gauge data: Journal of Hydrologic Engineering, v. 20, no. 11, p. $2285-2307$

Kingston, D.G., Todd, M.C., Taylor, R.G., Thompson, J.R., and Arnell, N.W., 2009, Uncertainty in the estimation of potential evapotranspiration under climate change: Geophysical Research Letters; v. 36, L20403. doi:10.1029/2009GL040267, accessed August 19, 2014, at http://onlinelibrary.wiley.com/doi/10.1029/2009GL040267/ $p d f$.

Markstrom, S.L., Hay, L.E., Ward-Garrison, C.D., Risley, J.C., Battaglin, W.A., Bjerklie, D.M., Chase, K.J., Christiansen, D.E., Dudley, R.W., Hunt, R.J., Koczot, K.M., Mastin, M.C., Regan, R.S., Viger, R.J., Vining, K.C., and Walker, J.F., 2012, Integrated watershed-scale response to climate change for selected basins across the United States: U.S. Geological Survey Scientific Investigations Report 2011-5077, 143 p., accessed August 19, 2014, at http:// pubs.usgs.gov/sir/2011/5077/. 
Markstrom, S.L., Niswonger, R.G., Regan, R.S., Prudic, D.E., and Barlow, P.M., 2008, GSFLOW-Coupled ground-water and surface-water flow model based on the integration of the Precipitation-Runoff Modeling System (PRMS) and the Modular Ground-Water Flow Model (MODFLOW-2005): U.S. Geological Survey Techniques and Methods 6-D1, 240 p., accessed August 19, 2014, at http://pubs.usgs.gov/ tm/tm6d1/pdf/tm6d1.pdf.

Moriasi, D.N., Arnold, J.G., Van Liew, M.W., Binger, R.L., Harmel, R.D., and Veith, T.L, 2007, Model evaluation guidelines for systematic quantification of accuracy in watershed simulations: Transactions of the American Society of Agricultural and Biological Engineers; v. 50, no. 3, p. $885-900$.

Nash, J.E., and Sutcliffe, J.V., 1970, River flow forecasting through conceptual models part I-A discussion of principles: Journal of Hydrology, v. 10, no. 3, p. 282-290.

National Oceanic and Atmospheric Administration, 2011, United States flood loss report-Water year 2011: National Oceanic and Atmospheric Administration, National Weather Service, accessed April 11, 2013, at http://www.nws.noaa. gov/hic/summaries/WY2011.pdf.

Schwarz, G.E., Hoos, A.B., Alexander, R.B., and Smith, R.A., 2006, The SPARROW surface water-quality modelTheory, applications and user documentation: U.S. Geological Survey, Techniques and Methods 6-B3, 248 p. and CD-ROM, accessed August 19, 2014, at http://pubs.usgs. gov/tm/2006/tm6b3/.

Singh, J., Knapp, H.V., and Demissie, M., 2004, Hydrologic modeling of the Iroquois River watershed using HSPF and SWAT. ISWS CR 2004-08, Champaign, Ill.: Illinois State Water Survey.

Sprague, L.A., Clark, M.L., Rus, D.L., Zelt, R.B., Flynn, J.L., and Davis, J.V., 2006, Nutrient and suspended-sediment trends in the Missouri River Basin, 1993-2003: U.S. Geological Survey Scientific Investigations Report 2006-5231, 80 p., accessed August 19, 2014, at http://pubs.usgs.gov/ sir/2006/5231/.

Strahler, A.N., 1952, Hypsometric (area-altitude) analysis of erosional topology: Geological Society of America Bulletin, v. 63, no. 11p, 1117-1142, doi:10.1130/00167606(1952)63[1117:HAAOET]2.0CO;2.

Thornton, P.E., Thornton, M.M., Mayer, B.W., Wilhelmi, N., Wei, Y., Cook, R.B., 2012, Daymet: Daily surface weather on a $1 \mathrm{~km}$ grid for North America, 1980-2012, accessed November 02, 2013, at http://daymet.ornl.gov/from Oak Ridge National Laboratory Distributed Active Archive Center, Oak Ridge, Tennessee, U.S.A.
U.S. Army Corps of Engineers, 2006, Missouri River mainstem reservoir system master water control manual Missouri River Basin, reservoir control center, U.S. Army Corps of Engineers, Northwestern Division-Missouri River Basin: Omaha, Nebraska, accessed August 19, 2014, at www.nwd-mr.usace.army.mil/rcc/reports/mmanual/ MasterManual.pdf.

U.S. Department of Agriculture, 1994, State Soil Geographic (STATSGO) data base-Data use information: Soils Conservation Service, National Cartography and GIS Center, Fort Worth, Texas.

U.S. Geological Survey, 2012, National hydrography dataset: U.S. Geological Survey, accessed April 30, 2012, at http:// nhd.usgs.gov/.

U.S. Geological Survey, 2013, U.S. Geological Survey National Water Information System, accessed November 02, 2013, at http://waterdata.usgs.gov/nwis.

Viger, R.J., 2012, Geospatial fabric for a National hydrologic model using NHDPlus: Proceedings from the American Water Resources Association 2012 Annual Water Resources Conference, Nov. 12-15, 2012, Jacksonville, Fla.

Viger, R.J., 2014, Preliminary spatial parameters for PRMS based on the Geospatial Fabric, NLCD2001 and SSURGO, U.S. Geological Survey, accessed August 19, 2014, at http:// dx.doi.org/doi:10.5066/F7WM1BF7.

Viger, R.J., and Leavesley, G.H., 2007, The GIS weasel user's manual: U.S. Geological Survey Techniques and Methods, book 6, chap. B4, accessed August 19, 2014, at http://pubs. usgs.gov/tm/2007/06B04/.

Ward-Garrison, Christian, Markstrom, S.L., and Hay, L.E., 2009, Downsizer-A graphical user interface-based application for browsing, acquiring, and formatting time-series data for hydrologic modeling: U.S. Geological Survey Open-File Report 2009-1166, 27 p., accessed August 19, 2014, at http://pubs.usgs.gov/of/2009/1166/.

Watermolen, John, 2005, National Atlas of the United States, version 2.4: Reston, Virginia, 1:2,000,000 scale hydrologic unit boundaries.

Wells, J.V.B., 1955, Floods of April 1952 in the Missouri River basin: U.S. Geological Survey Water Supply Paper 1260-B, accessed August 19, 2014, at http://pubs.er.usgs. gov/publication/wsp1260B/.

Wolock, D.M., 1997, STATSGO soil characteristics for the conterminous United States: U.S. Geological Survey OpenFile Report 97-656, accessed August 19, 2014, at http:// pubs.er.usgs.gov/publication/ofr97656. 


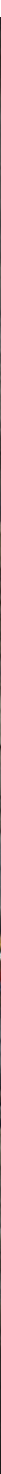

Drained scour hole west of Mound City, Missouri where Missouri Trooper Fred Guthrie and his K-9 Reed were swept away by floodwaters, November 2011. Photograph by Jeff Herzer (jeffherzer.com) and Missouri State Highway Patrol.

Pilot: Sgt. Kevin G. Haywood.

Publishing support provided by:

Rolla Publishing Service Center

For more information concerning this publication, contact:

Chief, USGS Office of Surface Water

415 National Center

12201 Sunrise Valley Drive

Reston, VA 20192

(703) 648-5301

Or visit the Office of Surface Water Web site at: http://water.usgs.gov/osw/ 


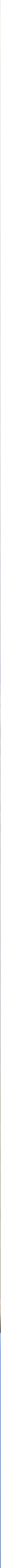